\title{
TESES DE DOUTORADO
}

1996 


\title{
ASSINE, Mario Luis
}

Aspectos da estratigrafia das sequências pré-carboniferas da Bacia do Paraná no Brasil. 26 de agosto. 207p. Orientador: Setembrino Petri.

Resumo: O registro pré-Carbonifero da Bacia do Paraná é composto por duas sequeências estratigráficas limitadas por discordâncias regionais, que constituem dois cicios de $2^{\mathrm{a}}$ ordem: Ordoviciano/Siluriano e Devoniano. No Ordoviciano Superior/Siluriano Inferior (Gr. Rio Ivaí) foram caracterizadas duas sequêencias deposicionais: 1) a inferior, considerada de idade caradociana - ashgilliana, compreende arenitos de tratos de sistemas transgressivo e de mar alto da Fm. Alto Garças, que apresentam mergulho deposicional para oeste em direção às bacias do $\mathrm{Chaco}$;2) a sequêtncia neoashgilliana - llandoveriana inicia-se com as fäcies subglaciais da Fm. lapó, correlacionadas com a glaciação gondwânica neoashgilliana. Folhelhos pós-glaciais da Fm. Vila Maria constituem trato de sistemas transgressivo, com superficie de máxima inundaçăo no Llandoveriano Inferior. A seção de topo da Fm. Vila Maria registra tendência regressiva, que culminou com a geração de discordância generalizada no Siluriano Superior. No Devoniano (Gr. Paraná) foram caracterizadas três seqüências deposicionais: 1) a sequência basal, de presumida idade lochkoviana, resultou de rápida transgressão sobre embasamento peneplanizado, em onlap de oeste para leste, fenômeno que gerou espaço para acomodação de tratos psamiticos de sistemas transgressivo e de mar alto (partes inferior e média da Fm. Furnas). A existência de traços fósseis de trilobita corrobora a interpretação de ambientes marinhos para a Fm. Furnas; 2) fácies conglomeráticas de trato de sistemas de mar baixo (parte superior da Fm. Furnas) marcam o inicio da seqüência praguianaeifeliana. O empilhamento é transgressivo na transição entre as formações Furnas e Ponta Grossa, com superfície de máxima inundação no Emsiano Superior (Mb. Jaguariaiva). O Eifeliano é caracterizado por trato de mar alto com empilhamento regressivo progradacional (Mb. Tibagi). Tectonismo sinsedimentar foi responsável pela individualização de altos internos e marginais, resultando no levantamento inicial do Arco de Assunção e na compartimentação das sub-bacias de Apucarana e Alto Garças; 3) a base da sequência givetiana-frasniana (Mb. São Domingos) é caracterizada por rápida inundação, com presença de lags transgressivos, à qual se associa o ingresso de águas quentes e o declíneo da fauna malvinocáfrica. A superficie de máxima inundação no Givetiano corresponde à máxima transgressão no Devoniano da Bacia do Paraná. Análise regional permitiu verificar a aplicabilidade da divisão tripartite da $\mathrm{Fm}$. Ponta Grossa em toda a bacia. Na faixa de afloramentos no Estado de Goiás o Mb. Jaguariaíva não ocorre e o contato com a Fm. Furnas é discordante, com presença de lags transgressivos. Na Chapada dos Guimarães a parte superior da Fm. Furnas de autores prévios foi reclassificada como Fm. Ponta Grossa. A sequêência devoniana é desigualmente preservada e recoberta em discordância levemente angular por unidades westphalianas do $\mathrm{Gr}$. Itararé. As sequeências ordovício-siluriana e devoniana são aproximadamente cronocorrelatas às orogenias pré-andinas Oclóyica (Ordoviciano Superior/Siluriano Inferior) e Chanica (Devoniano Médio/Mississipiano Inferior), evidenciando correspondência entre eventos de subsidência na bacia e orogenias nas bordas das placas.

\begin{abstract}
The pre-Carboniferous record of the Paraná Basin is composed of two stratigraphic sequences bounded by regional unconformities: 1) Ordovician-Silurian sequence, and 2) Devonian sequence. The Ordovician-Silurian stratigraphic sequence (Rio Ivai Group) is characterized by two depositional sequences. The oldest one (Caradocian/Ashgillian) is made up of sandstones (Alto Garças Formation), dipping westward to the Chaco basin, herein interpreted as transgressive and highstand systems tracts. The youngest sequence (Neoashgillian/Llandoverian) begins with subglacial facies of the lapó Formation, a correlative of several Gondwana Neoashgillian glacial records. The shales of the Vila Maria Formation (Lower Llandoverian) are the post-glacial flooding record and comprise the maximum flooding surface of the transgressive systems tracts. The upper section of the Vila Maria Formation records the regressive facies and a widespread unconformity in the Late Silurian. The Devonian stratigraphic sequence (Paraná Group) is made up of three depositional sequences: 1) the lowermost one (Lochkovian?) records, from west to east, a coastal onlap over the basement comprising the transgressive and highstand systems tracts of the Furnas Formation (lower and middle sections). The presence of trilobite trace fossils in the Furnas Formation are important diagnosis for its marine environment. 2) The middle sequence (Praguian/Eifelian) is composed of conglomerates of lowstand system tract and transgressive facies toward the contact zone with Ponta Grossa Formation. The maximum flooding surface was in the Late
\end{abstract}


Emsian during the deposition of the Jaguariaiva Member. The Eifelian (Tibagi Member) is characterized by a progradational regressive stacking, typical of highstand systems tracts. Sinsedimentary tectonics were responsible for creating internal and marginal highs, such as the Asuncion Arch, and sub-basins such as the Apucarana and Alto Garças. 3) The uppermost sequence (Givetian/Frasnian) is a transgressive sequence (São Domingos Member) associated with warm currents bringing about the decline of the Malvinokaffric fauna. The Givetian maximum flooding surface overlaps the maximum transgression of the Devonian in the Paraná basin. The Devonian sequence is separated from the ltarare Group (Westphalian) by a slightly angular unconformity. The regional analysis performed in this work has also aimed the practical application of the three-fold subdivision of the Ponta Grossa Formation. It has been observed that the Jaguariaiva Member does not occur in the outcrop area of Goiás State and that the contact with the Furnas Formation, in that area, is discordant with transgressive lags. In the Chapada dos Guimarães area, Mato Grosso State, the upper part of the Furnas Formation of previous authors was reclassified as Ponta Grossa Formation. The Ordovician-Silurian and Devonian sequences in the Paraná Basin are chronocorrelated to the Oclóyica (Late Ordovician/Early Silurian) and Chanica (Middle Devonian/Early Mississippian) pre-Andean orogenic phases, showing correspondence between intraplate subsidence and orogenies in the plate edges.

\section{DINIZ, Hélio Nóbile}

Estudo do potencial hidrogeológico da Bacia Hidrográfica do Rio Baquirivu-Guaçu, municípios de Guarulhos e Arujá, SP. 25 de abril. 296p. Orientador: Uriel Duarte.

Resumo: A bacia hidrográfica do rio Baquirivu-Guaçu, situada nos Municípios de Guarulhos e Arujá, compreende uma área importante sob o aspecto de desenvolvimento regional e cuja demanda de água é em grande parte suprida através de poços tubulares profundos. Estes poços captam água em dois sistemas aquiferos: o sedimentar, por porosidade granular e o cristalino, por porosidade de fissuras.

$\mathrm{Na}$ área da bacia do rio Baquirivu-Guaçu, estão situados o Aeroporto Internacional de São Paulo e indústrias de médio e grande porte, principalmente metalúrgicas, de transformação de alimentos, quimicas e eletro-eletrônica, que são supridas através de água subterrânea captada por poços tubulares profundos.

O grau de poluição das águas superficiais, dos córregos e rios, torna o custo do tratamento inviável. Isto tem provocado um grande aumento na perfuração de poços tubulares profundos para suprir a demanda.

Neste trabalho foi cadastrada uma parcela significativa dos poços, equipados, desativados e soterrados e os dados geológicos e hidrogeológicos foram levantados, com o objetivo de definir, através de software digital de interpeloção, o SURFER versão 5.01 , as estruturas geológicas importantes para o armazenamento de água subterrânea e o histórico da situação de exploração. Os testes de vazão foram interpretados utilizando-se os softwares EXCEL versão 5.0 e o ORIGIN versão 3.5, para obter-se as caracteristicas hidrodinâmicas e o potencial de exploraçăo dos aquifferos. As análises quimicas efetuadas para a determinação da potabilidade foram interpretadas para a caracterização das águas subterrâneas através do software QUATTRO PRO versão 1.00 .

A localizaçăo dos poços e o estado atual de exploração foram investigados e confirmados no campo, sendo transformados em tabelas digitais. Utilizando o software SURFER versão 5.1 obteve-se mapas do contorno da bacia sedimentar, geometria dos aqüiferos e evolução dos níveis d'água em função da explotaçăo.

As séries históricas de dados hidrometeorológicos de postos situados na área foram inventariadas e os dados interpretados através do software BALASC e QUATTRO PRO versão 1.00. obtendo-se o balanço hídrico da bacia e o potencial de recarga dos aquíferos. As reservas de água subterrânea, renováveis e permanentes, foram calculadas e avaliadas.

Métodos de adequação do meio físico ao ciclo hidrológico são propostos, para a recuperaçăo dos aquiferos sujeitos à superexplotação e, par amortecer o picos das cheias provocadas pelo aumento do runoff. como conseqüência da impermeabilização dos terrenos causada pela ocupação urbana.

Abstract: The hydrographical basin of Baquirivu-Guaçu river, situated in the Guarulhos and Arujá 
Municipalities is an important area under the aspect of regional development and its water demand is greathly supplied by deep tubular wells. These wells collect water in two aquifer systems: the sedimentary one, by granular porosity and the cristaline one, by porosity of fissures.

The São Paulo international Airport are situated in the basin area of Baquirivu-Guaçu river and also medium and large sized industries, mainly o metallurgy, of food processing, chemical and electric-electronical ones, that are supplied by groundwater collected through deep tubular wells.

The degree of contamination of overground water, of streams an rivers, makes the cost of treatment prohibitive. This fact has caused a great increase of borehole perfuration to supply the demand.

In this work a significative number of equipped, desactivated an buried wells was registered and geological and hydrogeological data were surveyed. The objective was to define the main geological structures for the storage of underground water and also the history of the water exploration situation. Modern techniques of digital interpolation were used with the aid o EXCEL version 5.0, ORIGIN version 3.5, SURFER version 5.0 and QUATTRO PRO version 1.00 softwares. Discharge tests were performed to obtain the hydrodynamic characteristics and the potential exploration of the aquifers Chemical analyses were performed to determine the water drinkability and were interpreted to give a characterization of the groundwater.

The wells location and their present exploration state we confirmed with work field and it are transformed in digital charts. Contour maps of the sedimentary basin, the geometry of the aquifers and the evolution of water levels related with the explotation were also obtained.

Through historical series of hydrometeorological data inventoried the hydric balance in the basin area and the potential recharge of the aquifers were calculated.

The reserves of groundwater, renovable and permanent were assessed and calculated.

Methods of adequacy of the environment to the hydrological cycle are proposed for recovering the aquifers subject to over exploitation and also, to weaken the overflow peaks provoked by the runoff increase as a consequence of impermeabilization caused by human occupation.

\section{FASSBINDER, Elvo}

A Unidade Agua Clara no contexto do Grupo Açungui: um modelo transpressivo de colisão obliqua no Neoproterozóico paranaense. 08 de novembro. Orientador: Rômulo Machado.

Resumo: As litologias do Grupo Açungui, situadas no Estado Paraná, foram deformadas num regime transpressivo, em consequuência de uma convergência obliqua de placas. A deformação sofreu partição segundo as componentes de cisalhamento puro (thrust faults) e cisalhamento simples (transcorrências), ambas em regime de deformação dúctil. A componente de cisalhamento puro, melhor desenvolvida nas litologias da Formação Água Clara, gerou os sistemas de deformação $\mathrm{SD}_{1}, \mathrm{SD}_{2}$ e $\mathrm{SD}_{3}$. Destes sistemas, o $\mathrm{SD}_{1}$ é penetrativo, gerando foliaçōes $\mathrm{SS}_{(1)}$ e $\mathrm{Sc}_{(1)}$, dobras cerradas a isoclinais, lineações minerais e de estiramento. $\mathrm{O}$ sistema $\mathrm{SD}_{2}$, com as foliações $\mathrm{Ss}_{(2)}$ e $\mathrm{Sc}_{(2)}$, reativou e reorientou o sistema anterior $\left(\mathrm{SD}_{1}\right)$. E o sistema $\mathrm{SD}_{3}$ é composto pelas foliações $\mathrm{Ss}_{(3)}$ e $\mathrm{Sc}_{(3)}$. Estes sistemas sofreram superposição cinemática, com transportes para sul $\left(\mathrm{SD}_{1}\right)$, norte $\left(\mathrm{SD}_{2}\right)$ e sul $\left(\mathrm{SD}_{3}\right)$, respectivamente.

A segunda componente da partição, de cisalhamento simples, desenvolveu-se nas demais litologias do Grupo Açungui, na sequêencia da história deformacional. Foram geradas novas estruturas, além da reorientação daquelas pré-existentes. Seguiu-se um período de transtração, com a colocação de granitos nos Complexos Trẻs Córregos e Cunhaporanga (?). Este periodo foi sucedido por um novo evento transpressional, agora de natureza rúptil/dúctil, sendo também acompanhado por partição da deformação. Ao longo da componente de cisalhamento simples, predominante, desenvolveram-se os lineamentos transcorrentes da Lancinha, Morro Agudo, Itapirapuă, Ribeira, entre outros, além de dobras escalonadas e demais estruturas de Riedel. Ao longo desta componente, ocorreu a rotação do eixo X do elipsóide de deformação finita, passando de uma posição horizontal para vertical. Esta rotação da deformação somou-se aquela da componente de cisalhamento puro, gerando uma estrutura-em-flor, positiva. Esta estrutura alçou, no seu centro, com maior intensidade, o Complexo Três Córregos e a Formação Água Clara, diminuindo de intensidade em direçăo às suas bordas, expondo a Formação Votuverava, a sudeste, e mais afastadas destas, as formações Capirú e Itaiacoca, nas bordas sudeste e noroeste, respectivamente. 
A coluna estratigráfica original do Grupo Açungui, com a Formação Ảgua Clara na base, seguida da Formação Votuverava e, no topo, as formaçōes Capirú e Itaiacoca, sofreram inversão tectônica ao longo da estrutura-em-flor, positiva. Os dados de isótopos estáveis de ${ }^{18} \mathrm{O}$ sugerem um intervalo de 400-450 Ma para a sedimentação destas unidades, com idade próxima de 1,3 Ga, para a Formação Água Clara, de $0,90 \mathrm{Ga}$ para a Formação Votuverava e, próxima de $0,70 \mathrm{Ga}$, para as formaçб̃es Capirú e Itaiacoca.

Abstract: The lithological units of the Açungui Group, in the State of Paraná, were deformed in a transpressive regime as a consequence of an oblique plate colision. Both thrust faults and simple shearing took place in a ductile deformation regime. Pure shearing which was better developed in the Água Clara Formation generated $\mathrm{SD}_{1}, \mathrm{SD}_{2}$ and $\mathrm{SD}_{3}$ deformation systems; $\mathrm{SD}_{1}$ is penetrative, with $\mathrm{Ss}_{1}$ and $\mathrm{Sc}_{1}$ foliations, close to isoclinal folds, mineral and stretching lineations; $\mathrm{SD}_{2}$, with $\mathrm{Ss}_{2}$ and $\mathrm{Sc}_{2}$ foliations, reactivated and reoriented the $\mathrm{SD}_{1}$ system and $\mathrm{SD}_{3}$ is made up of $\mathrm{Ss}_{3}$ and $\mathrm{Sc}_{3}$ foliations. These systems underwent a kinematic superposition, with Southward $\left(\mathrm{SD}_{1}\right)$. Northward $\left(\mathrm{SD}_{2}\right)$ and again Southward $\left(\mathrm{SD}_{3}\right)$ transport.

Following the sequence of deformation events, the second component of the partition, consisting of simple shearing, developed in the remaining lithologies of the Açungui Group. Besides the reorientation of the existent structures, new ones were generated. A period of transtension thus followed, with the emplacement of granites in the Três Córregos and Cunhaporanga (?) Complexes. This period was succeeded by a new transpression event which had a ruptile/ductile behavior while a partition of the deformation also happened. Besides en échelon folding and other Riedel's structures, transcurrent faults (e.g. Lancinha, Morro Agudo, Itapirapuã, Ribeira) developed along the dominant simple shearing component. It was along this component that the finite deformation ellipsoid $\mathrm{X}$ axis rotated, changing for horizontal to vertical position. This rotation of the deformation added up to that of the pure shearing component, generating a positive flower structure, which uplifted, in its center, the Três Córregos Complex and the Agua Clara Formation. Towards the structure limits, the Votuverava Formation was exposed at Southeast, and Capirú and Itaiacoca formations at Southeast and Northwest, respectively.

The original stratigraphy of the Açungui Group, with the Agua Clara Formation in the base, followed by the Votuverava Formation and with Capiru and ltaiacoca Formations on top, experienced a tectonic inversion throughout the positive flower structure. Stable isotopes of ${ }^{18} \mathrm{O}$ data suggest an interval of 400-450 Ma for the sedimentation of these units, with ages of $1.3 \mathrm{Ga}$ for the Água Clara Formation, $0.90 \mathrm{Ga}$ for Votuverava and around $0.70 \mathrm{Ga}$ for Capirú and ltaiacoca formations.

\section{FERNANDEZ, Victor Velázquez}

Provincia Alcalina Alto Paraguai: caracteristicas petrográficas, geoquímicas e geocronológicas. 28 de março. 101p. Orientador: Celso de Barros Gomes.

Resumo: A Provincia Alto Paraguai localiza-se na divisa do Estado do Mato Grosso do Sul com o Paraguai, entre as coordenadas $21^{\circ} 10^{\prime}$ a $23^{\circ} 25^{\prime}$ de latitude Sul e $57^{\circ} 10^{\prime}$ a $58^{\circ} 00^{\prime}$ de longitude Oeste, e tem como principal ponto de referência a cidade de Porto Murtinho.

O domínio geotectônico da área é governado pelas unidades pré-cambrianas da extremidade sul do Cráton Amazônico, que desenvolveu prolongada e acentuada atividade, gerando dobramentos e importantes falhas que, em muitos casos, parecem ter exercido um efetivo controle nas manifestaçø̃es magmáticas.

Levantamentos geológicos realizados permitem reconhecer numerosas intrusões na forma de diques, plugs, domos, stocks e complexos anelares, ocupando sempre a parte mais elevada da região. Petrograficamente, esses corpos congregam duas associaçōes sieniticas distintas, insaturada e saturada em silica, caracterizando, assim, litologias diversas que gradam desde nefelina sienitos, nefelina-sodalita sienitos, sienitos alcalinos a quartzo sienitos, com alguns extremos chegando até sienogranitos.

As análises de elementos maiores quando colocados no diagrama AFM mostram alta concentração no vértice $\mathrm{Na}+\mathrm{K}$, indicando clara afinidade alcalina, como já sugerido pela paragênese mineralógica (nefelina, feldspato potássico, além de piroxênio e anfibólio sódico como fases máficas importantes). Por outro lado, a modelagem dos elementos hidromagmatófilos permite distinguir duas 
tendências principais ligadas a diferentes mecanismos de evolução: sienitos alcalinos passando para quartzo sienitos e sienogranitos, e nefelina sienitos evoluindo para nefelina-sodalita sienitos.

Os dados radiométricos disponiveis indicam que a época de colocação dos corpos sieniticos se deu no periodo Permo-Triássico, com maior incidência no intervalo $260-240 \mathrm{Ma}$, caracterizando, assim, importante etapa de afinidade magmática alcalina, que se acredita única no gênero junto à Bacia do Paraná, uma vez que as demais conhecidas (Provincias Central, Amambay e Rio Apa, Paraguai; Provincia Velasco, Bolivia) apresentam idade bem inferior, entre 140-120 Ma.

As rochas sieniticas da Provincia Alto Paraguai mostram ampla variação da razão inicial ${ }^{87} \mathrm{Sr} /{ }^{86} \mathrm{Sr}$, cobrindo intervalo de 0,703361 a 0,707734 . Notadamente, os nefelina sienitos, exceção feita às rochas do Cerro Boggiani ( $0,703837-0,767734)$, apresentam valores mais baixos, $0,703361-0,703672$. Já os sienitos alcalinos exibem variação entre $0,703510-0,703872$, enquanto que os quartzo sienitos e sienogranitos possuem valores mais elevados, respectivamente, 0,704562 e 0,707076 .

As evidências de campo, juntamente com os dados petrográficos, geoquímicos e isotópicos $(\mathrm{Sr})$, sugerem que as rochas sieniticas derivaram de um liquido parental mantélico único, por processos de cristalização fracionada - e assimilação, por ocasião da colocação do magma na crosta.

Abstract: The Alto Paraguay Province is located at the border of the State of Mato Grosso do Sul and Paraguay, between the coordinates $21^{\circ} 10^{\prime}$ to $23^{\circ} 25^{\prime}$ of southern latitude and $57^{\circ} 10^{\prime}$ to $58^{\circ} 00^{\prime}$ western longitude, having the city of Porto Murtinho as the main reference point.

The geotectonic domain of the area is governed by the precambric units of the southern extreme of the Amazonic Craton which developed a long and accentuated activity, giving rise to folds and important faults, that in several cases seem to have exerted an effective control on the magmatic manifestations.

Field data allow to recognize several intrusions in the form of dykes, plugs, stocks and annelar complexes, always corresponding to the higher topographic points of the region. Petrographically, these bodies congregate two distinct syenitic association, unsaturated and saturated in silica, and include diverse lithologies grading from nepheline syenites, nepheline-sodalite syenites, alkaline syenites to quartz syenites, in addition to some extreme members as syenogranites.

Plots of major elements in the ternary diagram (AFM) show high concentration of analyses in the vertice $\mathrm{Na}+\mathrm{K}$, which suggests a clear alkaline affinity, as also indicated by mineralogic paragenesis (nepheline, potassium feldspar, and pyroxene/amphibole sodic as important mafic phases). On the other hand, by modelling the hydromagmatophile elements two main trends, related to different evolution mechanisms, can be distinguished: alkaline syenites, grading to quartz syenites and syenogranites, and nepheline syenites evolving to nepheline-sodalite syenites.

Radiometric data indicate that the emplacement of the syenitic bodies took place in the Permo-Triassic period, with a major incidence in the interval 260-240 Ma, representing thus, an important phase of alkaline magmatic affinity associated to the Paraná Basin, which is believed is to be unique, since the other known areas (Central, Amambay and Rio Apa Provinces, Paraguay; Velasco Province, Bolivia) are considerably younger (140-120 Ma).

Syenitic rocks from the Alto Paraguay Province show wide variation in the ratio ${ }^{87} \mathrm{Sr} /{ }^{86} \mathrm{Sr}$ (0.703361-0.707734). Excluding the Cerro Boggiani rocks (0.703837-0.707734), values for the nepheline syenites $(0.703361-0.703672)$ general lower than those of other syenites types. Alkaline syenites cover the interval $0.703510-0.703872$, while quartz syenites and syenogranites are 0.704562 and 0.707076 , respectively.

Geologic evidence, in addition to petrographic, geochemical and isotopic ( $\mathrm{Sr}$ ) data, suggest that the syenitic rocks have been derived from an unique mantelic parental liquid, by fractional cristallization and assimilation processes, which are assumed to bee occurred during the emplacement of the magma in the crust.

MANOEL FILHO, João

Modelo de dimensão fractal para avaliação de parâmetros hidráulicos em meio fissural. 25 de outubro. 197p. Orientador: Aldo da Cunha Rebouças. 
Resumo: O método da capacidade especifica fractal foi desenvolvido pelo autor para análise de testes de produção realizados com vazão variável. Isto porque, em geral, os dados de bombeamento de poços perfurados em meio fissural e/ou cárstico, que são tipicamente heterogêneos, costumam apresentar, entre outras coisas, variações na vazão bombeada. Essas variaçōes afetam as curvas de rebaixamento e recuperação com o tempo, complicando a interpretação dos testes pelos métodos convencionais, todos eles, como se sabe, desenvolvidos para vazão constante.

Admite-se que a evolução da capacidade especifica do poço, observada nas condiçōes de campo, $y\left(Q_{i} s_{t}\right)=Q_{i} I s_{i}$ (com o rebaixamento), pode ser aproximada por uma lei de potência do tipo $y\left(Q_{s} s_{t}\right) \cong y^{*}=Q^{*} l S_{I}^{D}$, onde $Q^{*} \dot{e}$ a descarga fractal uniforme e $D$ a dimensão do fluxo fractal para o poço. Os conceitos de dimensão de fluxo e de fluxo fractal uniforme equivalente, introduzidos no presente trabalho, são fundamentais na avaliação dos parâmetros do meio fissural e podem ser considerados como a principal contribuição da tese para a hidráulica de poços em meio fissural.

Somente as propriedades hidráulicas de transmissão (transmissividade, abertura média das fraturas, condutividade hidráulica, permeabilidade) e de armazenamento (porosidade) do condutor hidráulico representado pelo conjunto poço-fendas-blocos associados, podem ser calculadas, já que o modelo se aplica apenas no poço bombeado. Parâmetros de resposta elástica e de difusão (coeficiente de armazenamento, difusividade), bem como de filtraçäo vertical, do manto de cobertura indiferenciada para as fendas subjacentes, somente podem ser identificados por um modelo que também estude o fluxo fora do poço, isto é, no plano $(r, z)$. No caso, o modelo escolhido como mais apropriado para isso foi o de Boulton \& Streitsova (1977), com o qual todos os parâmetros do meio fissural) podem ser identificados, mediante substituiçăo do rebaixamento especifico $S I Q$, pelo inverso da capacidade específica fractal $I / y^{*}$.

O modelo foi aplicado na interpretação de 86 etapas de rebaixamento e 75 medições de recuperação, correspondentes a 86 testes de produção realizados em 72 poços, distribuídos por diversas subprovincias hidrogeológicas brasileiras e nas llhas Oceânicas de Fernando de Noronha - Pernambuco e Roatán, na República de Honduras. Essas aplicações forneceram as primeiras estimativas de propriedades hidráulicas obtidas pelo autor, em meio fraturado e cárstico. As ordens de grandeza das aberturas de fissuras são compativeis com resultados de estudos recentes, desenvolvidos na Alemanha em zona de falhas de alta permeabilidade (Himmelsbach et al., 1994). As porosidades estimadas são compativeis com resultados típicos para fraturas em poços de $60 \mathrm{~m}$ (Snow, 1968).

Abstract: The fractal specific capacity approach has been developed by the author for analysing single well production test data under variable discharge rate conditions. Pumping test data from wells drilled in a typical heterogeneous fractured and/or karstic medium usually present, among other things, discharge rate variations. Such variations affect time drawdown and time recovery curves thus complicating the well test analysis by conventional methods, which are only valid for constant discharge conditions. The observed well specific capacity, under field conditions, $y\left(Q_{t}, s_{l}\right)=Q_{l} l s_{t}$, (with drawdown), may be approximated by a power law of the type $y\left(Q_{t} s_{0}\right) \cong y^{*}=Q^{*} I s_{t}^{D}$. where $Q^{*}$ is a uniforme fractal discharge and $D$ a fractal flow dimension. The flow dimension and equivalent uniform fractal flow concepts, are basic tools for fractured media parameter evaluation and in that respect they are supposed to be the dissertation's main contribution to well hydraulics in fissured rocks.

Parameter identification through the proposed method is only provided in the pumped well for hydraulic transmissive parameters (fracture transmissivity and fracture aperture, hydraulic conductivity and permeability) and storage parameters (porosity) for the hydraulic conductor, namely for the wellblock-fracture system. Physical properties for difusion and response (diffusivity and storavity coeficients) as well as for delayed yield from the weathered zone to the lower fractured rock domain may only be evaluated by using a flow model in the $(r, z)$ plane. This can be done through Boulton and Streltsova (1977) block-fracture model, by replacing the specific drawdown $s I Q$. for the inverse of the fractal specific capacity, $11 y^{*}$

The model has been applied for analysing 86 drawdown curves and 75 recovery curves from pumping tests performed in 72 wells distributed over several groundwater brazilian subprovinces and in two oceanic islands, namely Fernando de Noronha in Pernambuco and Roatán in Honduras. Preliminary estimations of hydraulic properties were obtained by the author in karstic and fissured media. The order of magnitude for fracture apertures is in agreement with recent studies carried out in Germany in a highly permeable fault zone (Himmelsbach et al., 1994). The order of magnitude for porosity estimates are also 
in agreement with typical results for fractures in $60 \mathrm{~m}$ deep wells, which are on the order of $0.0050 \%$ (Snow, 1968).

\section{MENDES, Julio Cezar \\ Caracterização petrogenética das bordas noríticas e charnoquitóides dos maciços de Venda Nova e Várzea Alegre-ES. 20 de agosto, 238p. Orientador: Ian McReath.}

Resumo: Os maciços intrusivos de Venda Nova e Várzea Alegre localizam-se na região centro-sul do Estado do Espirito Santo e são representantes do magmatismo tardi a pós-tectônico associado ao desenvolvimento do arco magmático de idade Brasiliana nessa região. Ambos possuem forma circunscrita e são inversamente zonados; além disto, têm em comum uma auréola de rochas noríticas e charnoquitóides distintamente desenvolvida em cada um deles. A porção aflorante nos dois maciços corresponde a raiz dos plutons, e eles estão encaixados em gnaisses orto e paraderivados de grau metamórfico anfibolito a anfibolito alto (maciço de Venda Nova) e anfibolito alto a granulito (maciço de Várzea Alegre).

Na parte interna do maciço de Venda Nova encontram-se gabros e monzogabros que estão totalmente envolvidos por sienomonzonitos e monzonitos. Entre os gabros e os sienomonzonitos desenvolveu-se uma zona mista destes litotipos. Um estreito e irregular anel de rochas noriticas e charnoquitóides circunda todo o conjunto nos seus bordos oeste, sul e sudeste. Porções sieniticas irregulares localmente aparecem em meio ao domínio charnoquitóide.

São escassos os afloramentos dos noritos e dos charnoquitóides. Eles são rochas de estrutura maciça e homogênea, mas localmente a foliação de fluxo é mais desenvolvida. Nos charnoquitóides ocorrem discretas zonas de cisalhamento dúctil, associadas a penetração de veios e diques pegmatóides. Exibem também enclaves microgranulares básicos e veios máficos sin-intrusivos, possivelmente de noritos, o que comprova o seu posicionamento simultâneo.

Os noritos são rochas cumuláticas com granulação fina e textura que varia de hipidiomórfica granular a intergranular, sendo localmente microporfiriticos. A sua mineralogia é plagioclásio $\left(\mathrm{An}_{54}\right.$ a $\mathrm{An}_{85}$ ), hornblenda, $\mathrm{OPX}, \mathrm{CPX}$, ilmenita, magnetita, apatita, zircão e rara biotita. $\mathrm{O}$ anfibólio e a magnetita são predominantemente secundários. Os charnoquitóides são classificados em enderbitos, opXquartzo-dioritos, opdalitos e jotunitos. São rochas de granulação média, leucocráticas a mesocráticas e que possuem textura granular hipidiomórfica a porfiritica. Compõem-se de plagioclásio $\left(\mathrm{An}_{30} \mathrm{a} \mathrm{An}_{45}\right)$, quartzo, biotita, OPX, CPX, hornblenda, feldspato alcalino, ilmenita, magnetita, pirita, apatita e zircão. Zoneamentos mais significativos foram detectados nos plagioclásios dos noritos. Texturas de desequilibrio mineral geradas em estado subsolidus foram identificadas nos noritos e nos charnoquitóides. Os piroxênios são substituidos por anfibólios e biotitas, exsolvendo minerais opacos, e magnetita substitui ilmenita e piroxênios. Observam-se feições de deformação incipiente no estado dúctil.

Os Mg\# dos minerais máficos dos noritos são inferiores aos dos charnoquitóides, ao contrário dos valores obtidos para as rochas, que mostram Mg\# na mesma ordem de grandeza para as duas seqüências, apesar deles serem bem menores que os dos minerais. As tie lines traçadas para os piroxênios evidenciam cristalização em equilíbrio. As composiçōes dos anfibólios e das biotitas variam muito pouco, dificultando a identificação de possiveis cristais primários. Os $\mathrm{KdsFe}-\mathrm{Mg}$ próximos de 1 indicam cristalização em equilibrio para ambas as fases.

A utilização do geotermômetro OPX-CPX forneceu temperaturas de equilíbrio da ordem de $920^{\circ} \mathrm{C}$ nos noritos e de $970^{\circ} \mathrm{C}$ nos charnoquitóides. As prováveis temperaturas de subsolidus, calculadas por meio do par ilmenita-magnetita, foram de cerca de $600^{\circ} \mathrm{C}$ e o valor da $\mathrm{fO}_{2}$ obtida indica um ambiente redutor na geraçăo dessas rochas. As pressōes estimadas para o final da cristalização das rochas se situam em tomo de 5,5 a $6 \mathrm{~kb}$

A quimica de rocha separa duas sequências: uma básica, com características toleíticas, que corresponde aos cumulatos noriticos e outra intermediária, Ca-alcalina de médio $\mathrm{K}$, compreendendo os charnoquitóides. Diferem completamente do quimismo apresentado pelas rochas da porção interna do maciço de Venda Nova, que possuem tendência alcalina.

As duas sequências apresentam características quimicas gerais similares: caráter metaluminoso, enriquecimento em $\mathrm{Ca}, \mathrm{Fe}$ e $\mathrm{Al}$ e valores moderados a baixos de elementos incompativeis, 
Mg\# com a mesma ordem de grandeza e semelhança nos padrões de terras raras. Os spidergram das duas sequências exibem anomalias negativas de elementos $\mathrm{HFS}(\mathrm{Nb}, \mathrm{P}, \mathrm{Ti}$ e $\mathrm{Zr}$ ), comprovando que a origem das rochas está associada a processos de subducção, como indicam os diagramas de discriminação tectônica.

Os diagramas de variação mostram trends lineares para os charnoquitóides, que foram interpretados como refletindo uma evolução por cristalização fracionada a partir de um magma básico, em condições anidras e redutoras, e controlada por plagioclásio, OPX, CPX e ilmenita. Modelamentos efetuados indicam ser provável tal hipótese. Quanto aos noritos, parecem corresponder a cumulatos do mesmo magma parental que evoluiu para a sequência charnoquitóide, mas também podem estar vinculados a um magma basáltico de afinidade toleiítica. Ambas as sequêências tiveram significativa contribuição de um manto normal ou empobrecido, e granada deve ter sido fase residual quando da fusão mantélica, haja visto os teores de ETRP dos noritos e charnoquitóides.

O maciço de Várzea Alegre mostra no centro gabros que são envolvidos por dioritos/quartzodioritos-monzodioritos e granitos megaporfiriticos. Granito a titanita ocorre como um pequeno stock próximo dos gabros e também na forma de diques que cortam os demais litotipos. Todo este conjunto é circundado por uma extensa e irregular auréola de rochas charnoquitóides, que estão representadas num grande número de afloramentos. Enquanto nos bordos sul e oeste esse anel é estreito, a leste e a norte ele é largo e forma serras de cotas elevadas com amplos lajedos e encostas. Entre os granitos megaporfiríticos e os gabros/dioritos ocorre uma ampla zona mista onde são vistas estruturas em rede com feiçōes típicas de mistura de magmas, além de litotipos com composiçōes intermediárias.

Os charnoquitóides são rochas megaporfiriticas, de cor verde escura, que exibem foliação bem desenvolvida próximo aos contatos e uma estrutura maciça quando distante dos mesmos. Exibem algumas heterogeneidades tais como: variação na quantidade de megacristais, as vezes num mesmo afloramento; presença de diques de provável composição diorítica e de enclaves microgranulares básicos com ou sem xenocristais de feldspato; veios pegmatóides que provocam descharnoquitização localizada e xenólitos das rochas encaixantes variavelmente assimilados. Quando afloram, os contatos com os gnaisses são bruscos e paralelos à foliação, enquanto que com os litotipos do dominio interno eles são normalmente interdigitados.

A composição mineralógica dos charnoquitóides é: plagioclásio $\left(\mathrm{An}_{32} \mathrm{a} \mathrm{An}_{40}\right)$, álcali-feldspato pertitico/mesopertita, OPX, biotita, hornblenda, ilmenita, magnetita, pirita, apatita, zircão e rara allanita. A textura é porfiritica, com megacristais de feldspato alcalino, plagioclásio e quartzo, que podem atingir até $6 \mathrm{~cm}$ de tamanho. A matriz tem granulação média a grossa e quando está apertada entre os megacristais é mais fina e parcialmente recristalizada. São observados efeitos de deformação incipiente no estado dúctil. Os cristais de OPX encontram-se parcialmente substituídos por biotita, anfibólio e minerais opacos e estão bem alterados. Biotitas e anfibólios primários podem ocorrer, mas a análise por microssonda não detectou variações nas suas composições. São observados cristais de feldspato alcalino substituindo plagioclásio e consideráveis variações nas concentrações de suas lamelas pertíticas. Os OPX săo bem ricos em $\mathrm{Fe}$, mas possuem $\mathrm{Mg \#} \mathrm{superior} \mathrm{aos} \mathrm{das} \mathrm{rochas} \mathrm{que} \mathrm{os} \mathrm{contém,} \mathrm{o} \mathrm{que} \mathrm{também} \mathrm{foi}$ constatado para os anfibólios e biotitas. As biotitas são ricas em Ti e Ba e o álcali-feldspato tem até $2,3 \%$ $\mathrm{BaO}$.

Estimativas da temperatura de cristalização do magma através da saturação de $\mathrm{Zr}$ e $\mathrm{P}_{2} \mathrm{O}_{5}$ resultou em valores da ordem de $950^{\circ} \mathrm{C}$. As temperaturas de reequilibro subsolidus calculadas através dos termômetros ilmenita-magnetita e plagioclásio-feldspato alcalino deram próximas a $550^{\circ} \mathrm{C}$ para o primeiro par e de $630^{\circ} \mathrm{C}$ para os feldspatos. $\mathrm{A} \mathrm{fO}_{2}$ calculada através do par ilmenita-magnetita resulta em valores compativeis com um ambiente fortemente redutor, corroborado pelos baixos $\mathrm{Mg} \#$ das rochas. As pressð̃es de consolidação estimadas para os vários litotipos da borda do maciço de Várzea Alegre são de 6,5 a $7 \mathrm{~kb}$.

Os charnoquitóides de Várzea Alegre são quimicamente classificados em OPX-quartzodioritos, opdalitos, jotunitos e quartzo-mangeritos. São rochas ricas em elementos incompativeis, inclusive terras raras e elementos $\mathrm{HFS}$, como $\mathrm{Zr}$ e Nb. Os padrōes de ETR são bem fracionados e exibem discretas anomalias positivas de Eu. Possuem quimismo álcali-cálcico e no aranhograma apresentam anomalias negativas de Ti e P, comprovando origem associada a fenômenos de subducção.

Nos diagramas de variação convencionais pôde-se verificar uma possivel acumulação de feldspatos em algumas amostras. Através de gráficos de elementos incompativeis versus elementos 
compatíveis foram separados dois grupos de rochas com diferentes comportamentos: um evoluiu principalmente por cristalização fracionada de um magma intermediário e o outro por mistura de magmas, em condiçōes anidras e num ambiente redutor; modelamentos geoquimicos indicam ser possivel esta hipótese. A fusão parcial da crosta inferior, induzida por residência de um magma basáltico, deve ter possibilitado tal mistura de magmas. O magma básico provavelmente se formou pela fusão parcial de um manto previamente enriquecido em elementos incompativeis, inclusive alguns HFS.

Abstract: The intrusive massifs of Venda Nova and Várzea Alegre are situated in the central-southern portion of the Espirito Santo State. They are examples of the late to post-tectonic magmatic activity related to the development of the Brasiliano magmatic arc in this region. They constitute inversely zoned plutons with an almost circular shape. Both of these structures are surrounded by a distinctly developed ring of noritic and charnockitic rocks. The lithotypes that now outcrop in the massifs reveal the roots of the plutons. Their host rocks are ortho and paragneisses of amphibolite/high-amphibolite metamorphic grade (Venda Nova pluton) and high-amphibolite/granulite metamorphic grade (Várzea Alegre pluton).

The inner part of the Venda Nova massif comprises gabbros and monzogabbros completely surrounded by syenomonzonites and monzonites. An irregular and narrow ring of charnockites and norites involves these rocks in the west, south and southeast borders of the massif. Gabbros and syenomonzonites interfinger in a mixing zone. Locally small and irregulars syenitic schlieren occur in the charnockitic types.

The norites and charnockites rarely crop out. They have an homogeneous and massive structure, and the foliation is only locally well marked. Small ductile shear zones are observed in the charnockites, associated with the intrusion of pegmatitic veins and dykes. The presence of basic microgranular enclaves as well as mafic, probably noritic, syn-intrusive veins in this lithology is proof of their simultaneous emplacement.

The norites are fine grained cumulatic rocks with granular hypidiomorphic to intergranular texture. They are locally microporphyritic. Their mineralogical composition is plagioclase $\left(\mathrm{An}_{54}\right.$ to $\mathrm{An}_{85}$ ), hornblende, OPX, CPX, ilmenite, magnetite, apatite, zircon and scarce biotite. The amphibole and the magnetite are predominantly of secondary origin. The charnockites comprise enderbites, OPX-quartzdiorites, opdalites and jotunites. They are medium grained and leucocratic to mesocratic rocks, with granular hypidiomorphic to porphyritic texture. Their mineralogy is plagioclase $\left(\mathrm{An}_{30}\right.$ to $\left.\mathrm{An}_{45}\right)$, quartz, biotite, OPX, CPX, homblende, alkali feldspar, ilmenite, magnetite, pyrite, apatite and zircon. Zoned plagioclases are mainly observed in the norites. Textures of subsolidus mineral disequilibrium occur in the charnockites and norites. The pyroxenes are replaced by amphiboles and biotites, with exsolution of opaque minerals, and the magnetite replaces ilmenite and pyroxenes. Features of weak ductile deformation are observed.

The $\mathrm{Mg} /(\mathrm{Mg}+\mathrm{Fe})$ ratios of the mafic minerals of the norites are lower than those of the charnockites. In the rocks, these ratios are similar for the norites and charnockites, and lower than in the minerals. The tie lines of coexisting pyroxenes indicate crystallization in equilibrium. The chemistry composition of the amphibolites and biotites are almost constant and their $\mathrm{KdFe}-\mathrm{Mg}$ are close to 1.0 , pointing to equilibrium crystallization. The pyroxene geotermometers yielded temperatures of approximately $920^{\circ} \mathrm{C}$ for the norites and $970^{\circ} \mathrm{C}$ for the charnockites. Subsolidus temperatures of near $600^{\circ} \mathrm{C}$ were obtained using the pair ilmenite-magnetite. The low values of $\mathrm{fO}_{2}$ indicate reducing conditions during the formation of these rocks. The pressures estimated for their crystallization range from 5.5 to $6 \mathrm{~kb}$.

The whole rock chemistry separates two different sequences: a basic one, with tholeitic affinities corresponding to the noritic cumulates, and an intermediary one, medium $\mathrm{K}$ calc-alkalic comprising the charnockites. They show clearly different chemistry signatures when compared to the rocks of alkaline affinity of the inner domain of the pluton.

Both the sequences have similar geochemical characteristics: they are metaluminous, enriched in $\mathrm{Ca}, \mathrm{Fe}$ and $\mathrm{AI}$, and have low to moderate contents of incompatible elements. The $\mathrm{Mg} /(\mathrm{Mg}+\mathrm{Fe})$ ratios are so close and the REE patterns are similar. Negative anomalies of HFS elements in the spidergrams point to an origin related to subduction process, as indicated by the tectonic discriminant diagrams used.

In the charnockitic sequence the variation diagrams exhibits linear trends. These trends are interpreted as resulting from fractional crystallization of a basic magma controled by plagioclase, OPX, 
CPX and ilmenite, under anydrous and reducing conditions. Geochemistry modelling confirms such hypothesis. The norites may be cumulates from the same parental magma that evolved towards the charnockitic sequence. Nevertheless, they might also be associated to a tholeiitic basaltic magma. An expressive contribution of normal or depleted mantle is inferred for both sequences, and garnet probably were residual phase during mantle partial melting, indicated by the low contents of HREE.

The Várzea Alegre massif has at its center gabbros completely surrounded by diorites/quartzdiorites-monzodiorites and megaporphyritic granites. A finer-grained titanite granite occurs as a stock close to the gabbros and as dykes cutting all the lithotypes. All these rocks are involved by a large and irregular ring of charnockitic rocks, which crop out extensively. While in the south and west borders of the massif such ring is narrow, in the east and north borders it is very broad. A mixed zone marked by the presence of net veined structures with typical magma mixing features as well as the presence of hybrid rocks highlights the contact between the megaporphyritic granites and the gabbros/diorites.

The chamockites are dark green megaporphyritic rocks. They show a well developed foliation close to the contacts and a massive structure away from them. They also show some heterogeneities, like: variable amount of megacrysts, sometimes in the same outcrop; dykes of probable dioritic composition and basic microgranular enclaves with or without feldspar xenocrysts; pegmatitic veins that cause decharnockitization and xenoliths of gneisses variably assimilated. The contacts with the enclosed rocks are sharp and parallel to the foliation, and with the rocks of the inner domain they are generally interfingered.

The mineralogical composition of the charnockites is: plagioclase $\left(\mathrm{An}_{32}\right.$ a $\left.\mathrm{An}_{40}\right)$, perthitic alkali feldspar/mesoperthite, OPX, biotite, hornblende, ilmenite, magnetite, pyrite, apatite, zircon and rare allanite. The texture is porphyritic with megacrysts of alkali feldspar, plagioclase and quartz. The matrix is medium to coarse grained and it may be finer-grained when compressed and partially recrystallized among the megacrysts. The OPX are partly replaced by biotite, amphibole and opaque minerals. Primary biotites and amphiboles may also occur, but the microprobe analysis didn't detect variations in the compositions of these minerals. Alkali felsdspar replaces plagloclase and the concentration of the perthitic lamella is very variable. The composition of the OPX presents discrete variation. The mafic minerals are $\mathrm{Fe}$ rich and they have higher $\mathrm{Mg} /(\mathrm{Mg}+\mathrm{Fe})$ ratios than the rocks. The biotites are rich in $\mathrm{Ba}$ and the alkali feldspar has up to $4.2 \%$ of the celsian component.

The $\mathrm{Zr}$ and $\mathrm{P}_{2} \mathrm{O}_{5}$ saturation level indicates crystallizations temperatures of about $950^{\circ} \mathrm{C}$. The subsolidus temperatures obtained for the pairs ilmenite-magnetite and plagioclase-alkali feldspar were close to $550^{\circ} \mathrm{C}$ and $630^{\circ} \mathrm{C}$ respectively. The values calculated for the $\mathrm{fO}_{2}$ are consistent with highly reducing conditions, which is confirmed by the low $\mathrm{Mg} /(\mathrm{Mg}+\mathrm{Fe})$ ratios of the rocks. Estimates of the pressure of crystallization range from 6.5 to $7 \mathrm{~kb}$.

The charnockitic rocks of the Varzea Alegre massif have the following chemical classification: OPX-quartz-diorites, opdalites, jotunites and quartz-mangerites. They are rich in incompatible elements, including REE and HFS elements, such as $\mathrm{Zr}$ and $\mathrm{Nb}$. The REE patterns are fracionated and show small positive Eu anomalies. The chemical signature of the rocks is alkali-calcic, and in the spidergrams they present negative $\mathrm{Ti}$ and $\mathrm{P}$ anomalies, revealing an origin related to subduction process.

A possible acumulation of feldspars in some samples was inferred from the variation diagrams. Two groups of rocks were geochemically separated by means of incompatible versus compatible elements diagrams. One of these groups evolved mainly by fractional crystallization of a intermediate magma and the other one by magma mixing under anydrous and reducing conditions. Geochemical modelling confirmes this hypothesis. The mixing probably occurred after the partial melting of the lower crust, induced by underplating of a basaltic magma. The formation of such basic magma is probably related to partial melting of a previously enriched mantle source, including the HFS elements.

\section{OLIVEIRA, Míriam Cruxên Barros de}

Caracterização tecnológica do minério de crisotila da Mina de Cana Brava, GO, 23 de agosto. 250p. Orientador: José Vicente Valarelli.

Resumo: Este trabalho, de caráter multidisciplinar, procura efetuar a necessária integração entre 
Geologia e Engenharia através da caracterização tecnológica do minério da Mina de Cana Brava na sua forma bruta até o produto comercial (fibra beneficiada).

A Mina de Cana Brava, da S.A. Mineração de Amianto (SAMA), localiza-se no maciço de mesmo nome, no municipio de Minaçu (GO), responde por quase todo o amianto produzido no pais. A mineralização relaciona-se com serpentinitos associados a rochas metabásicas e metaultrabásicas do Maciço de Cana Brava. Estes serpentinitos são oriundos de hidrotermalismo sobre dunitos ou peridotitos. Cortando os serpentinitos ocorrem veios de crisotila com direções, comprimentos e espessuras muito variadas. A jazida consiste de duas cavas a céu aberto, A e B, nas quais se lavram os corpos de minério.

Para efetuar a caracterização global do minério desde a cava até o produto comercial, foram estudados: a rocha in natura, o material com granulometria $<0,074 \mathrm{~mm}$ procedente da rocha britada e da rocha britada atritada, a fibra de crisotila no seu estado bruto, semi-bruto e beneficiado. Na rocha, os estudos, de caráter inédito, foram petrográficos e tecnológicos; nas fibras, foram mineralógicos e tecnológicos Nas fibras brutas as propriedades mecânicas foram enfatizadas, por serem estas as mais importantes para a utilização no cimento-amianto. Todos os parâmetros obtidos nos vários ensaios efetuados, nos diversos tipos de materiais, foram correlacionados entre si. Observou-se que os tipos de serpentinito são facilmente distinguidos não só do ponto de vista macroscópico, como nos aspectos petrográfico e fisico-mecânico.

O serpentinito tipo I (SP-1), de cor marrom, é caracterizado pela presença freqüente de minerais silicáticos remanescentes do protólito ultramáfico (olivina e piroxênio); os minerais do grupo das serpentinas são geralmente antigorita e/ou lizardita, secundados por crisotila, e os opacos são hematita $e$ magnetita. Estas características petrográficas o tornam mais resistente mecanicamente, principalmente à compressão uniaxial. As fibras beneficiadas procedentes do SP-1 apresentam teores mais elevados de finos $(<0,074 \mathrm{~mm})$ e conseqüentemente, menores valores de indice de comprimento e de resistência à flexão.

O serpentinito tipo 2 (SP-2), de cor verde, é caracterizado pela ausência dos minerais originais da rocha-mãe, sendo constituido predominantemente por serpentinas, das quais a crisotila é a mais comum; o mineral opaco principal é a magnetita. Como consequência desta mineralogia, o SP-2 é menos resistente à compressão e à abrasão; as fibras beneficiadas dele precedentes exibem menores teores de finos $(<0,074 \mathrm{~mm})$, maiores valores de indices de comprimento e de resistência à flexão.

e SP-2.

O serpentinito tipo $1 / 2(\mathrm{SP}-1 / 2)$ apresenta geralmente caracteristicas intermediárias entre SP-1

O estudo mineralógico e mecânico das fibras brutas, foi realizado em duas etapas; na $1^{2}$, procurou-se desenvolver um método adequado para medir sua resistência à tração; na $2^{\mathrm{a}}$, as fibras foram caracterizadas mineralógica e mecanicamente, revelando excelente. qualidade e alta resistência à tração, com valores muito próximos para todas as amostras analisadas, tanto ả temperatura ambiente, como após aquecimento a $300^{\circ} \mathrm{C}$ e a $500^{\circ} \mathrm{C}$.

Foi efetuado ainda, pela primeira vez, um estudo mineralógico do material com granulometria $<0,074 \mathrm{~mm}$, proveniente da rocha britada e da rocha britada atritada, de forma a se conhecer o comportamento de cada mineral frente aos processos de britagem e atrição.

Observou-se que o comportamento dos minerais é diferenciado em relação ao tipo de processo mecânico envolvido (abrasão, britagem, atrição) e também em relação ao tipo de serpentinito.

O estudo tecnológico das fibras semi-brutas e beneficiadas permitiu sua caracterização e discriminação por tipo de serpentinito.

Finalmente, através da interação dos vários estudos setorizados verificou-se que o entendimento das caracteristicas e propriedades da fibra beneficiada sāo dependentes, nāo só da natureza da fibra bruta, como da rocha hospedeira e de como ambas se comportam frente aos processos de desmonte, extração e beneficiamento.

Abstract: This multidisciplinary work aims to achieve an integration of Geology and Engineering by technological characterization of the Cana Brava Mine ore from its crude state up to the milling fiber.

The Cana Brava Mine belongs to the S.A. Mineração de Amianto (Sama) and is located in the like-named massif at the Minaçu country (GO). This mine accounts for nearly all the brazilian asbestos production.

The mineralization took place in serpentinites which occur intermingled with the metabasic 
and metaultrabasic rocks of the Cana Brava Massif. The serpentinites were produced by hydrothermal action on dunites and peridotites. Chrysotile veins in variable directions, lengths and thicknesses cut the serpentinite body. The ore bodies are worked in two open pits, A and B.

In order to make a global characterization of the ore, studies were executed on the natural rock, in the $<0.074 \mathrm{~mm}$ grain-size material coming from both crushed and ball-milling rocks, and also on the crude fiber and fibers from pilot-plant and milling plant. Petrographical, mineralogical and technological unpublished studies were carried out in rock and in fiber samples. Being of major importante for the utilization of the asbestos-cement, the mechanical properties of the fiber were emphasized. The results obtained in analyses for the different types of material were correlated. it was found out that serpentinite types are easily distinguished under the physico-mechanical, petrografic and macroscopic point of view.

The brown serpentinite type 1 (SP-1) frequently contains reliquiar silicate minerals (olivine and pyroxene); the serpentine minerals are usually antigorite and/or lizardite, with some chrysotile, and the opaque minerals are hematite and magnetite. Such petrographical composition makes the rock more resistant to mechanical stresses, especially to the uniaxial compression. The milling fiber from SP-1 generates a larger volume of $<0,074 \mathrm{~mm}$ powder and therefore lesser length indices and weaker flexure strength.

On the other hand, the green type 2 (SP-2) serpentinite does not contain minerals from the mother rock. It is constituted mainly by serpentines, among which chrysotile is most frequent. The chief opaque mineral is magnetite. As a consequence, the SP-2 is less resistant to compression and abrasion, its milling fiber contains less $<0,074 \mathrm{~mm}$ powder and exhibit larger length indices and stronger flexure strength.

The properties of the type $1 / 2$ serpentinite (SP $1 / 2$ ) are usually intermediate between the ones of SP-1 and SP-2.

The mechanical and mineralogical study of the crude fibers was effected in two stages; firstly, a proper way to measure the tensile strengh was searched for and, secondly, the fibers were found to be of prime quality and display close figures of high tensile strength for all analyzed samples, at a room temperature, or at $300^{\circ} \mathrm{C}$ and $500^{\circ} \mathrm{C}$.

Mineralogical examination of the $<0,074 \mathrm{~mm}$ grain-size material was performed for the first time, on both crushed and ball-milling rock, so that the response of each mineral to the crushing and attrition processes has become known. Each process (abrasion, crushing, attrition) presented different results, according to the type of serpentinite analyzed.

By technological examination it was possible to characterize and distinguish pilot-plant and milling fibers related to the various serpentinites.

Finally, joining the several partial study results one could deduce that characteristics and properties of the milling fibers depend not only on the nature of the crude fiber as well as on the host rock and also how they behave under the processes of blasting, mining and milling.

\section{SILVA, Alexandre Pessoa da}

Mercúrio em ambientes aquáticos de Poconé - MT. 13 de dezembro. 118p. Orientador: Raphael Hypolito.

Resumo: Buscando dimensionar a participação do transporte aquático na contaminação ambiental foram realizados, no periodo entre 1989 e 1994, ensaios com sedimentos e determinados os teores de mercúrio total nos compartimentos ambientais água, sedimentos e material particulado em suspensão das drenagens diretamente impactadas pelas atividades garimpeiras, no município de Poconé.

Além do rio Bento Gomes, foram investigados seus principais afluentes que drenam o Município de Poconé, representando ambientes diretamente impactados e vias de transporte do poluente para o Pantanal.

Neste trabalho foi desenvolvido um dispositivo que permitiu detecção e determinação de mercúrio total em solos e sedimentos com teores de 0,1 a $100 \mathrm{ppm}$.

O processo consiste essencialmente em volatilizá-lo da amostra através de aquecimento, na sua absorção em solução ácida oxidante, seguida de sua extração com solução de ditizona em solventes 
orgânicos e na determinação de seu teor por comparação colorimétrica dos ditizonatos formados com padrōes.

Através desta nova metodologia, foram analisadas amostras de sedimentos do córrego Tanque dos Padres, o que permitiu detectar a existência de focos de contaminação onde a concentração de mercúrio total nos sedimentos chega a $34 \mathrm{ppm}$.

Ensaios realizados com amostras de sedimentos coletados em áreas sob influência direta das emissões de rejeitos, com baixa concentração de matéria orgânica e enriquecida em óxidos de ferro, e em áreas de dominio do Pantanal, ricas em matéria orgânica, apresentaram adsorção superior a $99 \%$ do mercúrio na forma iônica.

Em amostras de água brutas a concentração de mercúrio total apresentou valores entre 120 $\mathrm{ng} / \mathrm{l}$ no rio Bento Gomes, na estiagem e $1.342 \mathrm{ng} / \mathrm{l}$ no córrego Piraputanga, no periodo das chuvas.

Os teores de mercúrio total nas amostras de material particulado em suspensão oscilaram entre 55 e $1.425 \mathrm{ppb}$, sendo as maiores concentrações encontradas nas amostras coletadas no periodo das chuvas nos córregos Piranema e Piraputanga.

Os teores de $\mathrm{Hg}$ total nas amostras de sedimentos analisadas variaram entre $92 \mathrm{e} 880 \mathrm{ppb}$, sendo as maiores concentrações determinadas nas amostras coletadas nos córregos Piraputanga ( $880 \mathrm{ppb})$ e Piranema ( $840 \mathrm{ppb})$ que apresentaram teores de matéria orgânica de $3,32 \%$ e $2,85 \%$, respectivamente. Nos sedimentos o mercúrio se concentra nas frações granulométricas mais finas, menor que $250 \mu$. Na fração granulométrica até $3 \mu$ o mercúrio total apresenta concentrações superiores em mais de 10 vezes a sua concentração na fração granulométrica entre 250 e $1.000 \mu$.

Os estudos assinalaram a baixa mobilidade do mercúrio metálico, emitido juntamente com os rejeitos de amalgamação. Por outro lado, principalmente na época das fortes chuvas, o material particulado torna-se uma eficiente via de transporte para o mercúrio iônico depositado nas camadas mais superficiais dos solos.

Abstract: To estimate the participation of water transport on the overall environmental pollution, tests have been performed between 1989 and 1994 on sediments. Furthermore, the concentration of mercury in the waters, the sediments and the suspended matter of rivers directly influenced by gold small miners (garimpos) at the Poconé township in Mato Grosso have been determined. Not only the main river Bento Gomes, but all the sidearms have also been investigated to cover the whole region of direct contamination and all ways of transport of this polluting material on his way to the Pantanal swamps. of 0.1 to $100 \mathrm{ppm}$.

A process has been developed to determine total $\mathrm{Hg}$ levels of soils and sediments in the range

By means of heating, $\mathrm{Hg}$ is volatilized from the sample, absorbed by oxidizing acid solutions and extracted with dithizon-solutions in organic solvents. The concentrations of the $\mathrm{Hg}$-salts of dithizon have been determined by classical colorimetric procedures.

By means of this method, sediments of the sideriver "Tanque dos Padres" revealed local high levels of contamination reaching $34 \mathrm{ppm}$ in sediments.

Analyses of sediments collected in regions of direct influence of the polluting small mining activities showed absorption of mercury in ionic form mainly enriched in iron oxide or with high organic matter but influenced by the hydrological Pantanal swamp system.

Water samples collected during the dry season showed about $120 \mathrm{mg} / \mathrm{l}$ (Bento Gomes river) and $1343 \mathrm{mg} / \mathrm{l}$ during the rainy season (Piraputanga river).

The mercury concentrations of the suspended matter, directly correlated with the content of organic matter, reached 55 to $1425 \mathrm{ppb}$. The high values have been determined during the rainy season in the rivers Piranema and Piraputanga.

The concentration of $\mathrm{Hg}$ in the sediments analysed showed levels of 92 to $880 \mathrm{ppb}$. The higher values typical for the rivers Piraputanga $(880 \mathrm{ppb})$ and Piranema $(840 \mathrm{ppb})$. These two rivers showed $3.32 \%$ and $2.85 \%$ of organic material respectively .

In the sediments, the mercury is concentrated in the sieve fraction smaller than $250 \mu$, whereby on finds up to 10 times higher concentrations at sizes of $3 \mu$ composed with the amount in the fraction from 250 to $1000 \mu$.

These studies showed a low mobility of $\mathrm{Hg}$ in its elementary form produced and distributed by 
the process of amalgamation. On the other hand, and especially during the rainy season, the suspended matter in rivers provides an efficient way of transport of $\mathrm{Hg}$ in ionic form absorbed in the uppermost level of soils.

\section{SZABÓ, Gergely Andres}

Petrografia da Suite Metaultramáfica da Sequência Vulcano-Sedimentar Morro do Ferro na região de sul a oeste de Alpinópolis, MG (Dominio Norte do Complexo Campos Gerais). 07 de novembro. 393p. Orientadora: Maria Angela Fornoni Candia.

Resumo: A petrologia da Suíte Metaultramáfica da Sequência Vulcano-Sedimentar Morro do Ferro foi investigada em uma área de aproximadamente $550 \mathrm{~km}^{2}$, abrangendo a região de sul a oeste da cidade de Alpinópolis, sudoeste do Estado de Minas Gerais. Os terrenos compreendidos pela Tese pertencem ao Dominio Norte do Complexo Campos Gerais (CCG), que corresponde a uma associação arqueana tipo granito-greenstone belt, incorporada ao extenso sistema de zonas de cisalhamento direcionais/transcorrentes anastomosadas, de evolução contínua/recorrente, conhecido como Zona (Cinturão) de Cisalhamento Campo do Meio, que delinea os contornos do antigo Cráton do Paramirim nestes dominios meridionais do Cráton do São Francisco. Na parte setentrional da área delimitada para estudo, o substrato arqueano, intensamente modificado em episódios tectono-metamórficos sucessivos proterozóicos, é recoberto pela sequeência metassedimentar psamo-pelítica alóctone do(s) Grupo(s) AraxáCanastra, e pelos metassedimentos autóctones carbonático-pelíticos do Grupo Bambui, estes também sotopostos à superficie de cisalhamento de baixo ângulo que separa o pacote metassedimentar alóctone do embasamento ortognáissico-migmatitico granitico com corpos metaultramáficos inclusos.

$\mathrm{Na}$ área estudada o Dominio Norte do CCG é compartimentado em três Faixas: Faixa Serra do Dondó, a norte, Faixa Córrego das Almas, central, e Faixa Mumbuca, meridional, definidas pelas suas associações litológicas caracteristicas, e pelas extensas descontinuidades estruturais, de traçado bem marcado na topografia, que as delimitam. Rochas metaultramáficas concentram-se em duas áreas de ocorrência: na Faixa Serra do Dondó, em três corpos maiores, dentre os quais se destaca o corpo principal situado ao longo do vale do Ribeirão da Conquista, a sul de Alpinópolis, além de uma série de corpos menores circunvizinhos, inclusos nos terrenos ortognáissicos - migmatiticos, tonalíticos/granodioriticos cisalhados/remobilizados; e na Faixa Mumbuca, onde a ocorrência principal corresponde a um corpo estreito, alongado, situado no vale do córrego homônimo; e vários corpos lenticulares menores que ocorrem dispersos ao seu redor. O padrão estrutural da área é marcado por zonas de cisalhamento de alto/médio ângulo anastomosadas, de direção geral predominante WNW/ESE, que envolvem núcleos poupados ou menos afetados pelo cisalhamento heterogêno recorrente.

A Sufte Metaultramáfica corresponde a um conjunto de rochas de filiação komatítica, intensamente reorganizado por processos teoctono-metamórficos. Texturas spinifex pseudomórficas podem ser ainda reconhecidas em núcleos lenticulares menos deformados da Faixa Serra do Dondó, onde a deformação foi menos pervasiva. Os tipos litológicos menores que acompanham as rochas metaultramáficas são formaçōes ferriferas, metapelitos variados, e anfibolitos, componentes de uma associação vulcano-sedimentar tipo greenstone belt. Dentre as rochas metaultramáficas, predominam os tipos portadores de Ca-anfibólio, que variam de $\mathrm{Mg}$-clorita-tremolita xistos/fels a olivina e/ou ortopiroxênio-hornblenda xistos/fels porfiroblásticos com espinélio e/ou clorita. Tipos ultramáficos menores, serpentinitos e talco xistos/esteatitos, são interpretados como derivados dos tipos portadores de Ca-anfibólio através de modificações metassomáticas ocorridas ao longo das zonas de cisalhamento. As texturas e paragêneses descritas nas amostras metaultramáficas sugerem condições de equilíbrio em mosaico em várias escalas, sobrepondo-se domínios desenvolvidos sob condiçōes progressivamente de grau mais elevado a dominios originados em etapas anteriores, não completamente reequilibrados.

Amostras selecionadas foram analisadas para elementos maiores, menores e traço, incluindo Elementos Terras Raras (ETR). Os resultados das análises indicam uma forte mobilidade química para a Suite por inteiro, porém, com base nas razões de elementos incompativeis menos móveis, $\mathrm{Ti}, \mathrm{Zr}$ e $\mathrm{Sc}$, foi possivel reconhecer um conjunto de amostras com características composicionais primárias, igneas, menos modificadas, que indicam protólitos komatíticos de tipo ADK - komatiitos empobrecidos em aluminio, com sugestão de contaminação por crosta continental, reforçada pela existência de cristais de 
zircão inclusos em amostras com textura spinifex. Os dados geoquimicos sugerem ainda evolução composicional da suite vulcânica, komatiítica, através do fracionamento principalmente de oiivina com Fo $\geq 93$, além da existência de um evento de alteração submarina "a frio", pré-metamórfica, que alterou principalmente os padrões de ETR, de maneira caracteristica.

A evolução metamórfica da Suite Metaultramáfica é modelada com base em três Estádios Metamórficos: o Precoce, que define a Paragênese fundamental Mg-clorita-tremolita/actinolita, o Progressivo Principal, no qual se desenvolvem os porfiroblastos de ortopiroxênio e olivina, sobre uma matriz definida, predominantemente, pela Mg-hornblenda, e o Tardio de Baixo Grau, que inclui as transformações metassomáticas que conduzem à serpentinização e talcificação generalizadas. As modificaçōes metamórficas do Estádio Progressivo estão vinculadas às variaçōes composicionais verificadas em Mg-cloritas e Ca-anfibólios com o incremento do grau metamórfico. O enriquecimento progressivo em Al das cloritas resulta na blastese de olivina e antofilita nas etapas iniciais do metamorfismo progressivo. A quebra final da clorita, definida pela reação $\mathrm{Mg}$-Clorita $\Leftrightarrow$ Olivina+ Ortopiroxênio+Espinélio $+\mathrm{H}_{2} \mathrm{O}$, ocorre quando o conteúdo em $\mathrm{Al}$ alcança valores de (x)Al $-1,2$. O enriquecimento concomitante em Al dos Ca-anfibólios, através das substituições combinadas tschermakíticas e edeníticas, modifica as relações de fase definidas pelo processo de quebra final da clorita, conduzindo, nos casos em que as substituições ocorrem em proporções próximas à pargasítica, ao consumo da olivina pela blastese do ortopiroxênio, e ao consumo do espinélio, através da incorporação do componente aluminoso ao anfibólio.

Abstract: A petrological study of the Metaultramafic Suite belonging to the Morro do Ferro MetaVolcano-Sedimentary Sequence was undertaken in an area covering approximately $550 \mathrm{~km}^{2}$, from the south to the west of Alpinópolis town, southwestern Minas Gerais State, Brazil. The terrains belong to the Northern Domain of the Campos Gerais Complex (CGC), an archean granite-greenstone belt type association incorporated into the extensive, anastomosing shearzone system, known as the Campo do Meio Shear Zone, which deliniates the contours of the more ancient Paramirim Craton in these meridional domains of the Brasiliano São Francisco Craton. In the northern part of the area, the archean substrate, intensively modified by successive tectono-thermal proterozoic episodes, is recovered by the allochtonous psamo-pelitic metasedimentary sequence of the Araxa-Canastra Group(s), and by the autochtonous carbonatic-pelitic metasediments of the Bambui Group, which is also overlain by the low-angle shear zone through which the allochtonous sequence was carried from west to east over the orthogneissic-granitic basement that includes the ultramafic bodies.

The Northern Domain of the CGC is subdivided into three sub-areas in the investigated area: Serra do Dondó sub-area, to the north, Córrego das Almas sub-area, in the central part, and Mumbuca sub-area, to the south, defined through the characteristic lithological association of each, and by the large structural discontinuities, well marked in the topography, which delimitate them. Ultramafic rocks are concentrated in two main occurrences. In the Serra do Dondo sub-area, as three large bodies, of which the largest one is that cut by the Ribeirão da Conquista, to the south of Alpinópolis, apart from a series of smaller, lenticular bodies intercalated in the surrounding tonalitic to granodioritic, sheared and remobilized orthogneissic-migmatitic terrains. In the Mumbuca sub-area, the main ultramafic occurrence is represented by a thin, elongate body, located in the Mumbuca Stream valley. Various lenticular, smaller bodies occur in the surroundings. The structural pattern of the area is made up by high to intermediate dip, anastomosing, largely WNW/ESE oriented shear zones, which envelope nucleii preserved from the recurrent heterogeneous shearing, like tonalitic remnants in the Serra do Dondo and Córrego das Almas sub-areas.

The Metaultramafic Suite is made up of a set of rocks of komatiitic origin, intensively modified by tectono-metamorphic processes. Pseudomorphic spinifex textures can still be recognised in lenticular nucleii preserved from deformation in the less pervasively sheared Serra do Dondo sub-area. The lesser rock types associated to the metaultramafic rocks are iron formations, metapelites, and amphibolites, identified as belonging to a greenstone belt type volcano-sedimentary association. Among the metaultramafic rocks, $\mathrm{Ca}$-amphibole-bearing types predominate, with variations from $\mathrm{Mg}$-chlorite schists and fels to green spinel and/or chlorite-bearing, porphiroblastic olivine and/or orthopyroxenehornblende schists and fels. Lesser uitramafic rock types, like serpentinites and talc schists, are considered to be originated from the Ca-amphibole bearing rocks through metassomatic modifications 
along the shear-zones. The textures and paragenetic associations of the ultramafic samples are indicative of mosaic equilibrium in various scales, with domains developed under progressively higher metamorphic grade overprinting those originated in previous stages, not completely reequilibrated.

Selected samples were analysed for major, minor and trace elements, including Rare Earth Elements (REE). The results indicate a strong chemical remobilization for the Suite as a whole, yet with the help of less mobile incompatible element ratios, like $\mathrm{Ti}, \mathrm{Zr}$ and $\mathrm{Sc}$, it was possible to identify a set of samples with less intensively modified primary, igneous chemical characteristics, which point towards ADK - Aluminium Depleted Komatiitic protolithes, possibly with continental crust contaminations to some degree, as suggested also by zircon crystals found in some spinifex-textured rocks. The chemical data also suggest a compositional evolution for the komatiitic suite mainly through the fractionation of an olivine with Fo content $\geq 93$, as well as a pre-metamorphic, "cold" submarine weathering event, which altered mainly the REE patterns in a characteristic fashion.

The metamorphic evolution of the Metaultramafic Suite is modeled through three Metamorphic Stages: the Precocious, during which the Mg-chlorite - Ca-amphibole fundamental paragenesis were developed, the Main Progressive, when the olivine and/or orthopyroxene porphyroblasts developed over a matrix made up mainly by Mg-hornblende, and the Late Lower Grade, which includes the metassomatic processes responsible for the widespread serpentinization and talcification. The metamorphic changes of the Main Progressive Stage are ascribed to the compositional variations in $\mathrm{Mg}$ chlorites and $\mathrm{Ca}$-amphiboles with increasing metamorphic grade. The progressive AI-enrichment in chlorites leads to the growth of olivine and anthophyllite at the beginning of the progressive metamorphism. The final breakdown of chlorite, through the reaction $\mathrm{Mg}$-Chlorite $\Leftrightarrow$ Olivine + Orthopyroxene+Spinel+ $\mathrm{H}_{2} \mathrm{O}$, occurs when its Al content reaches the (x)Al 1,2 value. The concurrent Alenrichment of the $\mathrm{Ca}$-amphiboles through combined tschermakitic and edenitic substitutions, modifies the phase-relations brought about by chlorite breakdown, leading, when substitutions in the Ca-amphiboles, occur in close to pargasitic ratios, to olivine consumption through orthopyroxene growth, and spinel consumption, when its aluminian component is incorporated by the amphiboles.

\section{VALLADARES, Claudia Sayão}

Evolução geológica do Complexo Paraíba do Sul, no segmento central da Faixa Ribeira, com base em estudos de geoguímica e geocronologia U-Pb. 19 de agosto. $147 \mathrm{p}$. Orientador: Wilson Teixeira.

Resumo: Na folha Volta Redonda 1:50.000, afloram duas sequeências de características genéticas distintas, que compreendem no âmbito do segmento central da Faixa Ribeira, o Domínio Tectônico Paraiba do Sul (DTPS) ou Dominio Tectônico Superior: uma basal paleoproterozóica ortoderivada, composta por ortognaisses granodioriticos a graniticos, com enclaves de rochas máficas e de calciossilicáticas, denominada de Unidade Quirino; e outra metassedimentar, subdividida informalmente em Unidade Três Barras, formada por biotita-gnaisses com intercalaçôes concordante de lentes hololeucogranitos, e Unidade São João, constituida por metapelitos com lentes de rochas calciossilicáticas e mármores sacaroidais. As unidades metassedimentares compreendem o Grupo Paraiba do Sul.

Intrudem a Unidade Quirino e o Grupo Paraiba do Sul duas suites granitóides, geradas em épocas distintas em relaçāo aos eventos metamórficos-deformacionais da orogênese Brasiliana: granitóides do Típo S, que apresentam a foliação principal, e que são contemporâneos ao evento metamórfico principal de fácies anfibolito alto (M1), relacionado à deformação regional D1+D2. Estes granitóides, denominados de granitóides do tipo Rio Turvo, não apresentam nenhum corpo significativo na área mapeada; e granitóides com posicionamento posterior ao evento metamórfico-deformacional principal, que são contemporâneos ao segundo pulso metamórfico, também de fácies anfibolito-alto (M2), relacionado à deformação regional D3. Desta última suite, na área em questão, ocorrem dois corpos significativos, designados de Getulândia e Fortaleza. A zona de cisalhamento Paraiba do Sul, uma megaestrutura relacionada à fase D3, subdivide o DTPS em dois subdominios: um a NW (Domínio Paraíba Norte) e outro a SE (Domínio Paraiba Sul). A área mapeada insere-se neste último subdomínio.

A Unidade Quirino, ocorre como extensos corpos de gnaisses homogêneos em fä́cies anfibolito alto, localmente migmatíticos, com hornblenda e/ou biotita, perfazendo ca. de $50 \%$ da área mapeada. Regionalmente integram por volta de $70 \%$ em superfície do Domínio Tectônico Paraíba do Sul 
no segmento central da Faixa Ribeira. A Unidade Quirino foi gerada a $2185 \pm 8 \mathrm{Ma}$ e $2169 \pm 3 \mathrm{Ma}$ (dados $\mathrm{U}-\mathrm{Pb}$ em zircão), e está temporalmente relacionada à evolução do ciclo Tranzamazônico. Estas idades, definidas por interceptos superiores de análises de zircőes, foram obtidas nos ortognaisses Quirino a sul e a norte da Zona de Cisalhamento do Rio Paraiba do Sul, respectivamente. As idades minimas de $2846 \mathrm{Ma}$ e $2981 \mathrm{Ma}$, obtidas em zircões dos gnaisses granodioriticos da Unidade Quirino, aflorantes ao norte da Zona de Cisalhamento Paraiba do Sul, revelam a pré-existência de crosta arqueana como fonte de $\mathrm{Pb}$ para parte dos gnaisses investigados

As investigaçōes geoquímicas realizadas nos ortognaisses Quirino, aflorantes ao sul da Zona de Cisalhamento Paraiba do Sul, levaram ao reconhecimento de duas sequências calcioalcalinas: uma de médio a alto-K (formada por gnaisses granodioríticos), e outra de alto-K, muito enriquecida em LILE (integrada por gnaisses graniticos). Estas duas seqüências podem ter sido geradas num mesmo evento colisional no Transamazônico. Os dados geoquímicos sugerem que seqüência calcioalcalina médio a alto$\mathrm{K}$ representa os estágios iniciais da colisão, assemelhando-se a granitóides calcioalcalinos pré-colisionais. A sequêencia calcioalcalina alto- $\mathrm{K}$, poderia representar os estágios finais desta colisão, assemelhando-se a granitóides pós-colisionais, gerados sob crosta espessada.

As linhas de discórdia definidas pelas análises de zircão dos ortognaisses da Unidade Quirino geraram interceptes inferiores de $605 \pm 3 \mathrm{Ma}$ e $571 \pm 3 \mathrm{Ma}$. Titanitas escuras dos ortognaisses graniticos forneceram idade máxima de crescimento deste mineral a $577 \pm 1$ Ma. Titanitas dos leucossomas de rocha metamórfica relacionada à Unidade Quirino revelam fusåo parcial a $584 \pm 2 \mathrm{Ma}$. Estes dados indicarn remobilização de rochas Unidade Quirino, durante a orogênese Brasiliana. Titanitas de rocha calciossilicática da Unidade São João forneceram idades ${ }^{207} \mathrm{~Pb} /{ }^{206} \mathrm{~Pb}$ minimas de $590 \mathrm{Ma}$, datando o metamorfismo no Grupo Paraíba do Sul. O metamorfismo M1 ocorreu entre 590-570 Ma, com pico metamórfico entre 577 e $584 \mathrm{Ma}$. Dentro deste intervalo de tempo, a $579 \pm 2 \mathrm{Ma}$ (dado U-Pb em monazita), ocorreu a intrusão do Granitóide sin-colisional Rio Turvo, inserido dentro do Domínio Tectônico Juiz de Fora ou Dominio Tectônico Central da Faixa Ribeira, subjacente ao DTPS. O conjunto destes dados caracteriza, no tempo, o metamorfismo M1 regional da orogênese Brasiliana, no segmento central da Faixa Ribeira.

Idades mais antigas, de $(605 \pm 3 \mathrm{Ma})$ obtidas pelo intercepto inferior de zircões dos gnaisses graniticos, e de $604 \pm 1 \mathrm{Ma}$, obtida em um cristal equidimensional da mesma amostra, podem refletir o inicio das atividades metamórficas relacionadas aos estágios iniciais de cavalgamento durante a orogênese Brasiliana.

Na unidade metassedimentar São João, no Dominio Paraíba Norte, ocorre um corpo de dimensões batolíticas, o Granito Taquaral, que tem posicionamento entre os eventos metamórficos regionais M1 e M2. O conjunto das idades ${ }^{207} \mathrm{~Pb} /{ }^{206} \mathrm{~Pb}$, obtidas em titanitas deste granito (553 Ma), em titanitas cor intermediária do gnaisse granítico da Unidade Quirino (563 Ma), e em titanitas do Granitóide Rio Turvo (551 Ma), indicam atividade metamórfica continua entre os pulsos metamórficos principais ou, alternativamente, rehomogeinização incompleta de titanitas mais antigas.

Os dados U-Pb obtidos em monazita do Granito Getulândia (535 $\pm 1-528 \pm 1 \mathrm{Ma}$ ), somados as investigações geoquimicas realizadas neste corpo e no Granito Fortaleza, datam o plutonismo calcioalcalino a álcali-cálcico tardi a pós-tectônico em relação a orogênese Brasiliana no segmento Central da Faixa Ribeira. A recristalização de titanitas nos ortognaisses da Unidade Quirino hả $535 \pm 2 \mathrm{Ma}$ e nos seus leucossomas há $535 \pm 2 \mathrm{Ma}$ e $530 \pm 2 \mathrm{Ma}$, respectivamente, e o crescimento de titanitas em lente leucossomática destes ortognaisses $(521 \pm 2 \mathrm{Ma})$, foram relacionadas ao segundo pulso metamórfico M2. Este metamorfismo pode ter atingido, pelo menos localmente, ao sul da Zona de Cisalhamento Paraiba do Sul, temperaturas de anatexia, já que as idades mínimas de formação de leucossomas nos gnaisses graníticos ( $530 \pm 2 \mathrm{Ma})$, são concomitantes com a intrusđ̃o do Granito Getulândia.

A idade de $503 \pm 2 \mathrm{Ma}$ em titanita do ortognaisse granitico é a mais nova obtida, refletindo a diminuiçã̃o da atividade metamórfica, concordante com a idade ${ }^{207} \mathrm{~Pb} /{ }^{206} \mathrm{~Pb}$ em titanita do granito póstectônico Mangaratiba ( $492 \pm 11 \mathrm{Ma}$ ), no Complexo Costeiro. Estas idades foram relacionadas a estágios pós-metamórficos e pós-deformacionais no segmento central da Faixa Ribeira, durante a orogênese Brasiliana.

Abstract: The Volta Redonda 1:50,000 quadrangle (Rio de Janeiro State, southeast Brazil) displays two rock sequences comprising the Paraiba do Sul Tectonic Domain (PSTD) or Upper Tectonic Domain, at 
the central segment of the Ribeira belt: the basal Quirino Unit, a Paleoproterozoic orthoderived suite, comprising granodioritic to granitic gneisses, with mafic and calc-silicate enclaves; and the Paraiba do Sul group, which includes metasedimentary biotite gneisses with concordant intercalations of hololeucogranites layers (Três Barras Unit) and metapelites containing calc-silicate and sacaroidal marble lenses (Såo Joåo Unit).

Two granitoid suites intrude the Quirino Unit and the Paraiba do Sul group, with distinct timing of generation, in relation to the deformational and metamorphic events of the Brasiliano orogeny: the Rio Turvo S-type foliated granitoids, contemporaneous with the main metamorphic event (M1) of upper amphibolite facies, related to the main regional deformation $(\mathrm{D} 1+\mathrm{D} 2)$ studied area. The other granitoid suite, represented by two mapped bodies, Getulândia and Fortaleza, post-dates the main deformational and metamorphic event, and is coeval with the second metamorphic event (M2), also of upper amphibolite facies, and related to the D3 deformation phase. The Paraiba do Sul shear zone, a D3 related megastructure, divides the PSTD in two sub-domains: the Northern Paraiba and the Southern Paraiba. The studied area is located in the latter.

The Quirino Unit occurs as extensive bodies of homogeneous gneisses of upper amphibolite facies metamorphism, locally migmatitic, with hornblende and/or biotite, comprising approximately $50 \%$ of the studied area and ca. $70 \%$ of the PSTD. This unit yields U-Pb zircon ages of $2169 \pm 1$ and $2185 \pm 8$ $\mathrm{Ma}$, temporally related to the Transamazonian event. These ages are defined by upper discordia intercepts and were obtained from Quirino orthogneisses from the Northern and Southern Paraiba sub-domains, respectively. Minimum ages of 2846 and $2981 \mathrm{Ma}$, obtained on zircons from the Quirino Unit granodioritic gneisses at the Northern Paraiba subdomain, reveal the pre-existence of Archean crust as $\mathrm{Pb}$ source of part of the investigated gneisses.

Geochemical studies of Quirino orthogneisses at the Southern Paraiba sub-domain discriminate two calc-alkaline series: one of medium to high-K (granodioritic gneisses) and the other one of high-K, with enrichment in LILE (granitic gneisses). These two series may have been generated in the same Transamazonian collisional event. The geochemical data suggest that the medium to high-K series represents the pre-collisional calc-alkaline magmatism and the high- $\mathrm{K}$ calc-alkaline series represents the post-collisional magmatism, generated in thickened crust.

The Quirino Unit orthogneisses yield lower intercepts in concordia diagrams at $605 \pm 3$ and $571 \pm 3 \mathrm{Ma}$. Dark sphene grains from granitic orthogneisses yielded maximum growth ages of $577 \pm 1 \mathrm{Ma}$. Sphene from leucosomes in mafic rocks from the Quirino Unit indicate partial fusion at $584 \pm 2 \mathrm{Ma}$. These data indicate reworking of the Quirino Unit rocks during the Brasiliano orogeny. Sphene from São João Unit calc-silicate rocks yields a ${ }^{207} \mathrm{~Pb} /{ }^{206} \mathrm{~Pb}$ minimum age of $590 \mathrm{Ma}$ for the metamorphism of the Paraiba do Sul group.

The first metamorphic event (M1), related to the Brasiliano orogeny, occurred between 590 and $570 \mathrm{Ma}$, with metamorphic peak between 577 and $584 \mathrm{Ma}$. During this time interval, U-Pb dating of monazite indicates the age of $579 \pm 2 \mathrm{Ma}$ for the intrusion of the sin-collisional Rio Turvo granite. This granite is located in the Central Tectonic Domain of the Ribeira belt, which underlies the PSTD.

Older U-Pb zircon ages of $605 \pm 3 \mathrm{Ma}$, given by the lower intercept of granitic gneisses, and of $604 \pm 1 \mathrm{Ma}$, of an equidimensional crystal from the same sample, may reflect the onset of metamorphic activity related to the initial stages of Brasiliano thrust stacking.

The Taquaral granite, a batholithic intrusive body in the São João Unit at the Northern Paraiba sub-domain, had its emplacement during the time interval between M1 and M2 metamorphic events. The ${ }^{207} \mathrm{~Pb} /{ }^{206} \mathrm{~Pb}$ ages on sphenes from this granite (553 Ma), from the Quirino Unit granitic gneiss ( $563 \mathrm{Ma}$ ) and from the Rio Turvo granite ( $551 \mathrm{Ma}$ ), indicate continuous metamorphic activity between the main metamorphic events or, alternately, incomplete rehomogenization of the older sphene.

The calc-alkaline to alkali-calcic late to post-tectonic plutonism, related to the Brasiliano orogeny, is dated by the U-Pb monazite ages of $535 \pm 1$ and $528 \pm 1 \mathrm{Ma}$, from the Getulândia granite, supported by petrogenetic studies of this body and of the Fortaleza granite. The age of the second metamorphic event (M2) is given by the ages of recrystallization of sphene from the Quirino Unit orthogneisses at $535 \pm 2 \mathrm{Ma}$; from the recrystallization ages of leucossomes at $530 \pm 2 \mathrm{Ma}$; and by sphene growth at the leucossomes at $530 \pm 2 \mathrm{Ma}$, which are coeval with the intrusion of the Getulândia granite.

The youngest age of $503 \pm 2 \mathrm{Ma}$, obtained on sphene from the granitic orthogneiss, reflect decrease of metamorphic activity, which is concordant with the ${ }^{207} \mathrm{~Pb} /{ }^{206} \mathrm{~Pb}$ age of sphene from the post- 
tectonic Mangaratiba granite $(492 \pm 11 \mathrm{Ma})$, located in the Costeiro complex. These young ages are related to post-metamorphic and post-kinematic stage of the Brasiliano orogeny at the central segment of the Ribeira belt.

\section{VELȦZQUEZ, Leila Nunes Menegasse}

Efeitos da urbanização sobre o sistema hidrogeológico: aspectos da recarga no aquífero freático e escoamento superficial - área piloto: sub-bacias Sumaré e Pompéia, município de Sâo Paulo. 18 de outubro. $172 \mathrm{p}$. Orientador: Uriel Duarte.

Resumo: Os efeitos da urbanização sobre a recarga aquiffera são freqüentemente mencionados na literatura em nivel qualitativo, com raros estudos abordando a sua quantificação.

O principal objetivo do presente estudo foi a avaliação da recarga direta e indireta no aquífero freático de uma área intensamente urbanizada. Duas sub-bacias contíguas (Sumaré e Pompéia) foram escolhidas como área piloto, ambas pertencentes à bacia do Rio Tietê, localizadas na porção cento-oeste do município de São Paulo, cobrindo uma área de $9,6 \mathrm{~km}^{2}$ e com um índice de impermeabilização total estimado em $73 \%$.

A área está geologicamente localizada na Bacia Sedimentar de São Paulo, de idade terciária, constituida de camadas e lentes arenosas, siltosas e argilosas, que cobrem $66 \%$ da área de estudos, com espessura média de $80 \mathrm{~m}$, e os $33 \%$ restantes são ocupados pelos aluviőes quaternários das várzeas do Rio Tietê. O desnivel altimétrico é bastante elevado $(111 \mathrm{~m})$, variando de 721 a 832 metros.

O regime climático é marcado por dois periodos, sendo um seco, de abril a setembro, e outro úmido, de outubro a março. A média anual de precipitação é de $1500 \mathrm{~mm}$.

O método para cálculo da recarga direta foi a medida direta, por um período de 14 meses, da oscilação do nível freático $\mathrm{em} 13$ poços de monitoramento perfurados para este fim. A profundidades desses poços variaram de 3,4 a $12,0 \mathrm{~m}$, e o nível d'água médio é de $2 \mathrm{~m}$ no aquífero quaternário e $7,3 \mathrm{~m}$ no nivel mais profundo do terciário.

A porosidade efetiva empregada no cálculo do armazenamento foi de 0,13 . A recarga total obtida representou aproximadamente $3,6 \%$ da precipitação anual ( $1818 \mathrm{~mm}$ - out/94-set $/ 95)$, e $25 \%$ da que seria obtida considerando-se uma situação de preocupação da bacia.

A recarga indireta correspondeu às perdas fisicas da rede de abastecimento de água (adutoras e ligaçōes domésticas). Com base em dados fornecidos pela Companhia de Saneamento Básico do Estado de São Paulo (SABESP), estimou-se uma perda total correspondente a $532 \mathrm{~mm}$, que representa cerca $89 \%$ da recarga total.

O estudo abrangeu ainda uma análise da eficácia dos microrreservatórios de retenção temporária, para controle de enchentes, previstos em lei do município de São Paulo. O amortecimento, em termos de volume, representou $30 \%$ do mínimo necessário. Os métodos empregados para cálculo do escoamento superficial e a geração dos hidrogramas, foram a equação de Horton e o método de Santa Bárbara, respectivamente.

Os resultados mostraram a significativa redução da infiltração devida à impermeabilização urbana e a necessidade de reformulação da Lei municipal de forma a tornar o sistema de microrreservatórios tecnicamente mais eficaz e a sua implantação economicamente viável do ponto de vista construtivo, de manutenção e fiscalização.

Abstract: The aim of this investigation was direct and indirect recharge evaluation of the freatic aquifers in a densely and urbanized area. The target area was two sub-basins in the Tietê River basin, city of São Paulo, Brazil. The Sumare and Pompéia sub-basins are localized in the middle-west of the city, the extend of area is $9.6 \mathrm{~km}^{2}$, and the impervious surface is approximately $73 \%$.

The study area is inserted in the Terciary Sedimentar Basin of São Paulo, constituted of sandy, silt and clay layers. This litology cover $66 \%$ of the area, about $80 \mathrm{~m}$ thick, and the other $33 \%$ are constituted by quaternary sediments Tietê River. The difference between altimetrics level is very accentuated, $111 \mathrm{~m}$ ( 721 to $832 \mathrm{~m}$ above sea level).

The rainfall pattern is characterized by the occurrence of a dry period between april and september and of a wet period from october to march. The mean annual rainfall is $1500 \mathrm{~mm}$. 
The evaluation method for direct recharge was realized by the direct measurements of the water table fluctuations of 13 monitoring wells during 14 months. The deep these wells varies of 3.4 to 12 $\mathrm{m}$, the mean freatic level is $2 \mathrm{~m}$ in quaternary aquifer and $7.30 \mathrm{~m}$ in the terciary aquifer.

Effective porosity was adopted constant for the total aquifer as a 0.13 . The overall recharge was $3.6 \%$ of the annual precipitation (1818 mm - october $/ 94$ to september $/ 95$ ), representing only $25 \%$ of the recharge that would have been achieved for the original basin conditions (without today urbanized on).

Indirect recharge actually corresponded water leakage from the public network of water supply (water mains and domestic connections). Based on data of supplied by São Paulo State Basic Sanitation Company (SABESP), the total estimated loss correspond to $532 \mathrm{~mm}$, i.e., $89 \%$ of the overall recharge.

In the study, was also analyzed the theoretic efficiency of the so called microreservoirs of temporary retention that, according to municipal laws, should be used for control floods. The mitigation in terms of volume represents only $30 \%$ of necessary minimum. The methods applied to estimate run off and to produce hidrograms were the indirect methods, the Horton equation and Santa Barbara, respectively.

The results showed significative infiltration losses due to urban impermebilization an the necessity of the reformulation of municipal laws in order to make the construction of microreservoirs effective, as well technical and economically feasible.

\section{VIEIRA, Silvia Regina Soares da Silva}

Estudo de processos metamórfico-metassomáticos nos Complexos Embu e Pilar no Bloco Juquitiba, SP. 17 de dezembro. 144p. Orientadora: Maria Angela Fornoni Candia.

Resumo: Este trabalho apresenta os resultados dos estudos sobre os processos metamorfismo/metassomáticos, que ocorrem entre os falhamentos de Caucaia e Cubatão, área equivalente ao Bloco Juquitiba (Hasui, 1973).

Em termos litológicos foram reconhecidos, entre os metamorfitos, duas unidades distintas, compostas por xistos finos e filitos, e por biotita xistos e gnaisses, correspondentes, respectivamente, aos Complexos Pilar e Embu, tais como definidos por Hasui (1975a).

Os estudos petrográficos e químicos revelaram a atuação de um evento metamórfico regional, que operou em condições do fácies xisto verde sobre as rochas do Complexo Pilar, e anfibolito, sobre as rochas do Complexo Embu. No Complexo Embu foi responsável pela recristalização da associação quartzo+plagioclásio+biotita \pm granada \pm opacos, presente em xistos e gnaisses reconhecidos esparsamente por toda a área estudada, mas, mais caracteristicamente, na região da Represa Billings.

As transformações de plagioclásio em fibrolita+quartzo e em muscovita, e de biotita em fibrolita/sillimanita e em muscovita, identificadas pela petrografia, levaram à modificação desta rocha, tida como original, em biotita xistos ou gnaisses muscovitizados e/ou fibrolitizados/sillimanitizados, em decorrência de um evento metamórfico metassomático superimposto.

As feições petrográficas e a comparação do quimismo dos minerais e rochas mais modificados com os dos mesmos minerais e rochas interpretados como originais, mostram a perda sistemática de sódio e cálcio e ganho de potássio com a transformação, caracterizando um processo metassomático, envolvendo mobilização iônica, segundo modelo semelhante aos de Hemley \& Jones (1964), Carmichael (1969), Vernon (1971) e Kwak (1971), entre outros.

A aplicação do geotermômetro granada-biotita e do geobarômetro anortita-grossulária$\mathrm{Al}_{2} \mathrm{SiO}_{5}$.quartzo resultou temperaturas entre $605^{\circ} \mathrm{C}$ e $772^{\circ} \mathrm{C}$, e pressões entre 5 kbar e 6 bkbar, interpretadas como as condiçōes de atuação do evento metamórfico regional, pré metassomático, sobre as rochas do Complexo Embu.

Não puderam ser determinadas as temperaturas e pressões metamórficas do evento superimposto, dada a inaplicabilidade dos geotermômetros e geobarômetros conhecidos à associação metassomática. Porém, metodologia alternativa, baseada em parâmetros cristalográficos da muscovita, permitiram estimar, qualitativamente, as condições vigentes à época do metassomatismo, como equivalentes às do campo de estabilidade da sillimanita, o que concorda com as observações petrográficas realizadas. 
Abstract: This Thesis presents the results of studies regarding the metamorphism of the proterozoic sequences which occur between the Caucaia and Cubatão fault zones, in the area ascribed to the Juquitiba Block (Hasui, 1973).

In lithological terms, two distinct metamorphic units were recognized, made up by finegrained schists and phyllites, and by biotite schists and gneisses, which correspond, respectively, to the Pilar and Embu Complexes, as defined by Hasui (1975a).

Petrographic studies revealed a regional metamorphic event developed under greenschist facies conditions in the Pilar Complex rocks, and amphibolite facies conditions in the rocks of the Embu Complex, which promoted the recrystallization of the quartz+plagioclase+biotite + garnet \pm opaques association found in schists and gneisses scattered all over the studied area and, more characteristically, in the region of the Billings Reservoir.

The transformation of plagioclase into fibrolite+quartz and into muscovite, and of biotite into fibrolite/sillimanite and into muscovite, as shown by the petrographic descriptions, led to the modification of these rocks, considered to be the original ones, into muscovitized and/or flbrolitized/sillimanitized schists and gneisses, due to a superimposed metamorphic event.

The petrographic features and the comparison of the chemical compositions of the most modified minerals and rocks with those considered to be the original ones show systematic $\mathrm{Na}$ and $\mathrm{Ca}$ losses and $\mathrm{K}$ gains through the transformations, thus characterizing a metassomatic process, with ionic mobility implied, in a fashion similar to those presented by Hemley and Jones (1964), Carmichael (1969), Vernon (1971) and Kwak (1971), among others.

The garnet-biotite geothermometer and the anorthite-grossular- $\mathrm{Al}_{2} \mathrm{SiO}_{5}$-quartz geobarometer yielded temperatures between $605^{\circ} \mathrm{C}$ and $772^{\circ} \mathrm{C}$ and pressures between 5 and 6 kbar for the rocks considered to be the original ones, interpreted as the conditions under which the regional, premetassomatic metamorphic event developed in the Embu Complex rocks.

The metarmorphic temperatures and pressures could not be obtained for the superimposed event, due to the lack of geothermometers and geobarometers suitable for the metassomatic association. Yet an alternative methodology, based on crystallographic parameters in muscovite, permitted estimating the conditions under which the metassomatic event developed as equivalent to those of the sillimanite stability field.

\section{WESKA, Ricardo Kalikowski}

Geologia da região diamantifera de Poxoréu e áreas adjacentes, Mato Grosso. 29 de outubro. 219p. Orientador: Darcy Pedro Svisero.

Resumo: Nesta Tese foram desenvolvidos estudos geológicos gerais na região diamantifera situada entre os Municípios de Dom Aquino General e Carneiro, cobrindo uma área de aproximadamente 12.000 $\mathrm{km}^{2}$. O trabalho inclui também estudos químicos e isotópicos de rochas básicas de natureza basáltica, bem como estudos de química mineral de granadas, ilmenitas e espinélios presentes em algumas rochas básicas/ultrabásicas, conglomerados e sedimentos de corrente.

Durante o mapeamento regional foi elaborada uma nova coluna estratigráfica, cuja sequeência da base para o topo, é constituída por um conjunto vulcânico-clasto-químico de idade cretácea, equivalente ao Grupo Bauru, englobando as Formaç̋̃es Paredăo Grande, Quilombinho, Cachoeira do Bom Jardim e Cambambe. Seguem-se a Formação Cachoeirinha de idade terciária-quaternária representando os eventos da Superficie Sul Americana na região, um pacote terciário-quaternário indiviso constituindo terraços laterais de drenagens, e por fim a Fácies Coité no topo da coluna englobando as aluviōes recentes. Essas duas últimas unidades encerram as minerações diamantiferas mais expressivas da regiāo, concentradas em torno de Poxoréu.

A Formação Paredão Grande é constituída por rochas equivalentes a basaltos do tipo OIB, datados em 83,9 $\pm 0,4 \mathrm{Ma}$. pelo método $\mathrm{Ar}^{40} / \mathrm{Ar}^{39}$, englobados na Província f́gnea de Poxoréu e resultantes da atividade da Pluma de Trindade sob o Estado de Mato Grosso. As Formações Quilombinho, Cachoeira do Bom Jardim e Cambambe, de idade cretácea superior, são constituídas por sequeências cíclicas de conglomerados, arenitos e argilitos conglomeráticos. A Formação Quilombinho é vulcano-derivada contendo mais de $90 \%$ de clastos da Formação Paredão Grande; a Cachoeira do Bom Jardim possui por 
volta de $50,0 \%$ desse tipo de clastos, e destaca-se pela presença de calcretes. A Cambambe, quase desprovida de clastos vulcânicos, caracteriza-se pela presença de silcretes. Seguem-se a Formação Cachoeirinha com cascalhos, areias, argilas e ferricretes; um pacote terciário/quaternário indiviso, e a Fácies Coité com deposições de cascalhos, areias e argilas.

Esse conjunto vulcano-clasto-quimico, formado por leques aluviais, desenvolveu-se em uma bacia do tipo rifte denominado neste trabalho de Rifle Rio das Mortes. A evolução geomorfológica do Cretáceo Superior ao Quaternário, sugere que essa Bacia Bauru depositou-se sobre uma paleosuperficie de meio graben, cujo depocentro estaria localizado sob o vale atual do Rio das Mortes. Esta bacia está sendo capturada pelos eventos erosivos e deposicionais da Bacia Intracratônica do Pantanal.

Os depósitos diamantíferos da área são representados por placers localizados junto às drenagens, sobretudo em torno da cidade de Poxoréu. O diamante possui distribuição heterogênea e seus depósitos mais ricos estão condicionados por armadilhas de pequeno a grande porte. Esse mineral ocorre desde os conglomerados cretáceos (fonte intermediária) até cascalhos recentes. Suas fontes primárias ainda não foram localizadas na região. Contudo, no decorrer desse trabalho detectamos a presença de um microdiamante em uma intrusão básica/ultrabásica alterada denominada Intrusão Tamburi.

Os minerais pesados granadas, ilmenitas e espinélios amostrados na Intrusão Tamburi, em piroclásticas da Formação Paredão Grande e em conglomerados da Formação Quilombinho, são constituidos por duas populações distintas, com caracteristicas químicas diferentes de kimberlitos. As evidências de campo sugerem que a Intrusão Tamburi poderia ser a fonte alimentadora dos depósitos quaternários junto à drenagem adjacente do Rio Paraíso. Entretanto, ela não poderia ter contribuido para os ricos depósitos situados nas circunvizinhanças de Poxoréu. Dessa forma a origem primária desses diamantes continua sendo uma questão em aberto.

Abstract: During this thesis we carried out a large amount of geological surveys in an area of 12,000 $\mathrm{km}^{2}$ located between the Municipalities of Dom Aquino and General Carneiro, central east Mato Grosso State, Brazil.

Field work revealed a new stratigraphic column whose sequence from the bottom to the top is characterized by volcanic-clastic-chemical rocks of Late Cretaceous age equivalent to the Bauru Group, encompassing the Quilombinho, Cachoeira do Bom Jardim and Cambambe Formations. Next in the column lies the Tertiary-Quaternary Cachoeirinha Formation representing the South American peneplanization in the area; an indivisible Tertiary-Quaternary sequence of terraces found along the fluvial system, and finally, the Coite Facies representing recent placers. The latter two units contain the rich diamond-bearing deposits which have been mined around Poxoréu in the last decades.

The Paredão Grande Formation is made up of basic rocks equivalent to OIB basalts, dated at 83.9 $\mathrm{Ma}$ by $\mathrm{Ar}^{40} / \mathrm{Ar}^{39}$ method. These rocks represent the magmatic events of the Poxoréu Igneous Province produced by the Trindade Plume under the State of Mato Grosso during the Late Cretaceous. The Late Cretaceous Quilombinho, Cachoeira do Bom Jardim and Cambambe Formations, are made up of cyclical sequences of conglomerates, arenites and conglomeratic clays. Furthermore, the Quilombinho Formation contains more than $90.0 \%$ volcanic clasts derived from the Paredåo Grande Formation. As for the Cachoeira do Bom Jardim Formation, calcretes are conspicuous but volcanic clasts so amount to around $50.0 \%$. The Cambambe Formation is enriched in silcretes produced by evaporation under arid conditions and depleted in volcanic clasts. The Cachoeirinha Formation is made up of gravels, sands, clays and ferricretes; the indivisible Tertiary-Quaternary unit and the Coité Facies are both composed of gravels, sands and clays.

This volcanic-clastic-chemical sequence developed as an isolated basin, herein named the Rio das Mortes Rift. Geomorphological evolution from the Late Cretaceous till the Quaternary suggests that this basin was developed upon a paleosurface of a half-graben. Its depocenter was located under the current Rio das Mortes Valley. Presently, the basin is being eroded by processes related to the Intracratonic Pantanal Basin.

Diamond-bearing deposits are widespread throughout the area, being particularly rich around the locality of Poxoréu. Diamond distribution is heterogeneous but the presence of traps accounts for concentrations worked in some diggings. Chemical analyses of pyrope garnets, magnesium ilmenites and chromium spinels recovered from pyroclastic rocks of the Paredão Grande Formation, Tamburi Intrusion, Quilombinho Formation and stream sediments revealed the presence of two distinct populations unrelated 
to kimberlites. The presence of a microdiamond recovered in the Tamburi intrusion could represent the source of some deposits but not of the entire diggings around Poxoréu. Therefore, the origin of Poxoréu diamonds still remains unknown. 